\title{
Review on Major Virulence Factors of Pathogenic Streptococcus Species
}

\author{
Umer Seid $^{1}$, Addisu Demeke ${ }^{2}$ \\ ${ }^{1}$ Oda Bultum University, Collage of Agriculture, Department of Animal Science, Chiro, Ethiopia. \\ ${ }^{2}$ Addis Ababa University College of Veterinary Medicine and Agriculture, Ethiopia.
}

*Corresponding Author: Umer Seid, Oda Bultum University, Collage of Agriculture, Department of Animal Science, Chiro, Ethiopia.

\begin{abstract}
Streptococcus species possesses a wide variety of virulence factors and can cause severe invasive infections. Accordingly, the field of bacterial pathogenesis has rapidly expanded with a greater understanding of pathogenesis at the molecular level over the last decades. The ability of bacteria to cause disease is described in terms of the number of infecting bacteria, the route of entry into the body, the effects of host defense mechanisms, and intrinsic characteristics of the bacteria called virulence factors. One essential prokaryotic cell function is the transport of proteins from the cytoplasm into other compartments of the cell, the environment, and/or other bacteria or eukaryotic cells a process known as protein secretion.Secreted proteins can play many roles in promoting bacterial virulence, from enhancing attachment to eukaryotic cells, to scavenging resources in an environmental niche, to directly intoxicating target cells and disrupting their functions. Virulence factors encoded on pathogenic islands represent the entire spectrum of bacterial virulence factors, from adhesins, toxins, secretion systems, invasins, modulins, effectors, proteases, lipases, and enterotoxins, superantigens, iron uptake systems, immunoglobulin A proteases, capsule synthesis, host defense avoidance mechanisms.
\end{abstract}

Keywords: Streptococcus, Bacteria, Proteins, Virulence

\section{Abbreviation}

SLO

C4BP

CAMP

CbpA

CBPs

CDCs

$\mathrm{CW}$

DNAases

FBP54

FBPs

FbsB

FCT

FHL-1

GAG

GAS

GBS

GRAB

GRAB

$\mathrm{H} 2 \mathrm{O} 2$

HA

HylA

\section{Streptolysin O \\ C4b-Binding Protein}

Factor Christie, Atkins and Munch-Petersen

Choline-Binding Protein A

Choline Binding Proteins

Cholesterol-Dependent Cytolysins

Cell Wall-anchored

Deoxyribonucleases

Fibronectin-Binding Protein 54

Fibronectin Binding Proteins

Fg-Binding surface protein $B$

fibronectin- and collagen-binding T-antigen

Factor H-like protein

Glycosaminoglycan

Group A streptococcus

Group B streptococcus

protein G-related $\alpha 2 \mathrm{M}$-binding protein

G-related $\alpha_{2}$ macroglobulin-binding protein

Hydrogen peroxide

hyaluronic acid

Hyaluronatelyase 


\begin{tabular}{ll}
\hline IdeS & IgG-degrading enzyme of S. pyogenes \\
IgA & ImmunoglobulinA \\
Lmb & Laminin-binding protein \\
MF & mitogenic factor \\
MSCRAMMs & Microbial Surface Components Recognizing Adhesive Matrix molecules \\
PAIs & Pathogenicity Islands \\
PAM & M-like protein \\
PI-1 & Pilus Island 1 \\
pIgR & poly-immunglobulin receptor \\
PrtF1 & Protein F1 \\
SC & Secretory Component \\
Sec & Secretion System \\
SfbI & Streptococcal fibronectin binding proteinI \\
SIC & Streptococcal Inhibitor of Complement-Mediated lysi \\
Ska & Streptokinase \\
SLS & Streptolysin S \\
SOF & Serum Opacity Factor \\
SPE-B & Streptococcal Pyrogenic exotoxin B \\
SRR & Serine-Rich Repeats \\
T3SS & Type Three Secretion System \\
T4SS & Type Four Secretion System \\
VFs & Virulence Factors \\
$\alpha 2 M$ & $\alpha_{2}$-Macroglobulin \\
&
\end{tabular}

\section{INTRODUCTION}

Despite advances in the prevention and treatment of infectious disease, pathogenic bacteria remain the pre-eminent threats to public and animals health worldwide(Waldvogel, 2004). Increasing antibiotic resistance strains and emerging and re-emerging infectious agents cause alarming new concerns(Byarugaba, 2004; Hogan and Kolter, 2002; Morens et al., 2004). Accordingly, the field of bacterial pathogenesis has rapidly expanded with a greater understanding of pathogenesis at the molecular level over the last decades. The ability of bacteria to cause disease is described in terms of the number of infecting bacteria, the route of entry into the body, the effects of host defense mechanisms, and intrinsic characteristics of the bacteria called virulence factors. The virulence of a pathogen refers to the severity of the clinical illness that results from infection. These proteins are coded for by genes in chromosomal DNA, bacteriophage DNA or plasmids(Keen, 2012). However, virulence factors (VFs) apply to the elements (i.e. gene products) that enable a microorganism to colonize a host niche where the organism proliferates and causes tissue damage or systemic inflammation. Conventional VFs include secreted proteins, such as protein toxins and enzymes, and cell-surface structures, capsular polysaccharides, lipopolysaccharides and outer membrane proteins, which directly contribute to the disease processes. Now, it becomes clear that many genes encoding virulence traits, such as secretion machineries, siderophores, catalases, regulators, etc. are indirectly involved in pathogenesis, which is equally important for bacteria to establish infection(Chen et al., 2005).

One essential prokaryotic cell function is the transport of proteins from the cytoplasm into other compartments of the cell, the environment, and/or other bacteria or eukaryotic cells a process known as protein secretion. Prokaryotes have developed numerous ways of transporting protein cargo between locations, which largely involve the assistance of dedicated protein secretion systems. Protein secretion systems are essential for the growth of bacteria and are used in an array of processes. Some secretion systems are found in almost all bacteria and secrete a wide variety of substrates, while others have been identified in only a small number of bacterial species or are dedicated to secreting only one or a few proteins(Green and Mecsas, 2016).

Virulence genes of pathogenic bacteria, which code for toxins, adhesins, invasins or other virulence factors, may be located on transmissible genetic elements such as transposons, plasmids or 
bacteriophages. In addition, such genes may be part of particular regions on the bacterial chromosome, termed 'Pathogenicity islands' (PAIs). They are present in the genome of pathogenic strains of a given species but absent or only rarely present in those of non-pathogenic variants of the same or related species(Hacker et al., 1997).PAIs found in both animal and plant pathogens. Additionally, PAIs are found in both gram-positive and gram-negative bacteria(Hacker et al., 1990). They are transferred through horizontal gene transfer events such as transfer by a plasmid, phage, or conjugative transposon(Hacker et al., 1997). So the objective of these review are

$\checkmark$ To review the virulence factor of pathogenic streptococcus species

$\checkmark$ To highlight secretion system and pathogenic island of pathogenic streptococcus species

\section{Virulence FACTOR OF STREPTOCOCCUS SPECIES}

Streptococci is the general term for a diverse collection of Gram-positive cocci that typically grow as chains or pairs. The genus Streptococcus includes important pathogens and commensals of mucosal membranes of the upper respiratory tract and, for some species, the intestines. The genus Streptococcus includes nearly 40 species. This species, which consists of Lancefield group A streptococci, is among the most prevalent of human and animals bacterial pathogens. It is exclusively associated with infections in man. It causes a wide range of suppurative infections in the respiratory tract and skin, life-threatening soft tissue infections, and certain types of toxin-associated reactions. Some of these infections may, in addition, result in severe non-suppurative sequelae due to adverse immunological reactions induced by the infecting streptococci(Kilian, 2002). Streptococcus spp. can colonize multiple sites in the human host; due to the strain-specific expression of 100 of fimbrial and afimbrialadhesins(Johnson, 2018a).

\subsection{Major virulence factor of Str. Pyogenes}

Strains of Str. pyogenes express a large arsenal of virulence factors and, hence, their pathogenicity and the clinical signs that they induce are very diverse. The virulence factors are involved in adherence, evasion of host immunity and tissue damage(Kilian, 2000). Fimbrialadhesins includes Pili, $\mathrm{M}$ protein and Afimbrialadhesins also includes MSCRAMMs (microbial surface components recognizing adhesive matrix molecules), Scl1, Scl2(cellular fibronectin), also there is Secreted adhesins: SPE-B (streptococcal pyrogenic exotoxin B), HylA(Hyaluronatelyase), Streptokinase (Ska), GRAB (protein G-related $\alpha 2 \mathrm{M}$-binding protein), Iron acquisition(Binding to host iron-containing proteins), Streptolysin O (SLO), Secreted phospholipase A; disrupts host cell membranes (SlaA), DNAases, Superoxide dismutase, C5a peptidase andLipoteichoic acid also mediates adhesion (Johnson, 2018a).

\subsubsection{Adherence}

Interaction with host fibronectin, a matrix protein on eukaryotic cells, is considered the principal mechanism by which Str. pyogenes binds to epithelial cells of the pharynx and skin. The structure that recognizes host fibronectin is located on the F protein, which is one of the many proteins expressed on the surface of Str. Pyogenes. The interaction between the streptococcal F protein and host cell fibronectin also mediates internalization of the bacteria into host cells. In addition to the F protein, surface-exposed lipoteichoic acid and $\mathrm{M}$ proteins appear to be involved in adherence to mucosal and skin epithelial cells(Thayer et al., 2008).

FBPs (Fibronectin binding proteins): It is surface protein that linked to the bacterial cell wall via Cterminal LPXTG motif. Including PrtF1 (protein F1) also known as SfbI (streptococcal fibronectin binding protein I), SfbII/SOF (serum opacity factor), FabA, FabB, FBP54 (fibronectin-binding protein 54), protein F2, PFBP (pyogene fibronectin-binding protein). They are used to binds to fibronectin via homologous repeat region. This domain promotes fibronectin-mediated collagen recruitment, which leads to matrix deposition on and between streptococcal cells to induce the formation of large bacterial aggregates. Furthermore, collagen-recruiting streptococci were able to colonize collagen fibres and were protected from adhering to human cells in the presence of opsonizing antibodies. PrtF1 also mediate internalization via integrins, fibronectin acts as an adapter molecule linking bacteria to the cell integrins(Kreikemeyer et al., 2004; Terao et al., 2001).Pilus: The GAS pili are encoded in the variable FCT (fibronectin- and collagen-binding T-antigen) region. The C-terminal domain of $\mathrm{Cpa}$, residues 286-723, mediates its adhesive properties and contains three domains: the middle domain (residues 291-372 and 590-597), the top domain (residues 390-583) and the bottom 
domain (residues 603-719). Involved in adherence to host cells and bioflim formation(Chamchaet al., 2015).

\subsubsection{Anti- Proteolysis}

GRAB (G-related $\boldsymbol{\alpha}_{2}$ macroglobulin-binding protein): It is surface protein that linked to the bacterial cell wall via C-terminal LPXTG motif, High affinity for $\alpha_{2}$-macroglobulin $\left(\alpha_{2} M\right)$ (proteinase inhibitor). It encoded by grab gene that is present in most $S$. pyogene strains and is well conserved. They used toRecruits the human protease inhibitor $\alpha_{2}$-macroglobulin to the surface of GAS to inhibit unwanted proteolysis, thus protecting the $\mathrm{M}$ proteins, and probably other surface structures, from proteolytic degradation(Mitchell, 2003; Toppel et al., 2003).

Hyaluronic Acid Capsule (hasA; hasB; hasC): Some strains of Str. pyogenes form a capsule composed of hyaluronic acid. Such strains grow as mucoid colonies on blood agar and are highly virulent in animal models. While capsule production is rare among isolates from uncomplicated pharyngitis, a significant proportion of isolates from severe infections have a capsule. Like other bacterial capsules it has an anti-phagocytic effect. The relative significance of the M protein and the capsule as anti-phagocytic factors differs among strains. The capsule is identical to the hyaluronic acid of the connective tissue of the host and is not immunogenic. The bacteria may, in this way, disguise themselves with an immunological 'self' substance(Fischetti, 1989). Its major virulence factors of many pathogenic bacteria as they are anti-phagocytic in nature. The hyaluronic acid capsule of $S$. pyogenes is non antigenic because of its chemical similarity to host connective tissue. Capsule of $S$. pyogenes thus assists the bacterium to hide its own antigens and to go unrecognized as antigenic by its host. The hyaluronic acid capsule also prevents opsonized phagocytosis (https://microbeonline.com/virulence-factors-streptococcus-pyogenes-roles/).

It composed of a polymer of hyaluronic acid containing repeating units of glucuronic acid and $\mathrm{N}$ acetylglucosamine. Thus, the capsule not only prevents phagocytosis by the usual route of discouraging C3b binding but makes the bacteria look like 'self' to the immune system. Binds to CD44 to induce marked cytoskeletal rearrangements manifested by membrane ruffling and disruption of intercellular junctions, thus promotes tissue penetration by GAS through a para cellular route. Transduction of the signal involved Rac1 and the cytoskeleton linker protein ezrin, as well as tyrosine phosphorylation of cellular proteins(Bisnoet al., 2003).

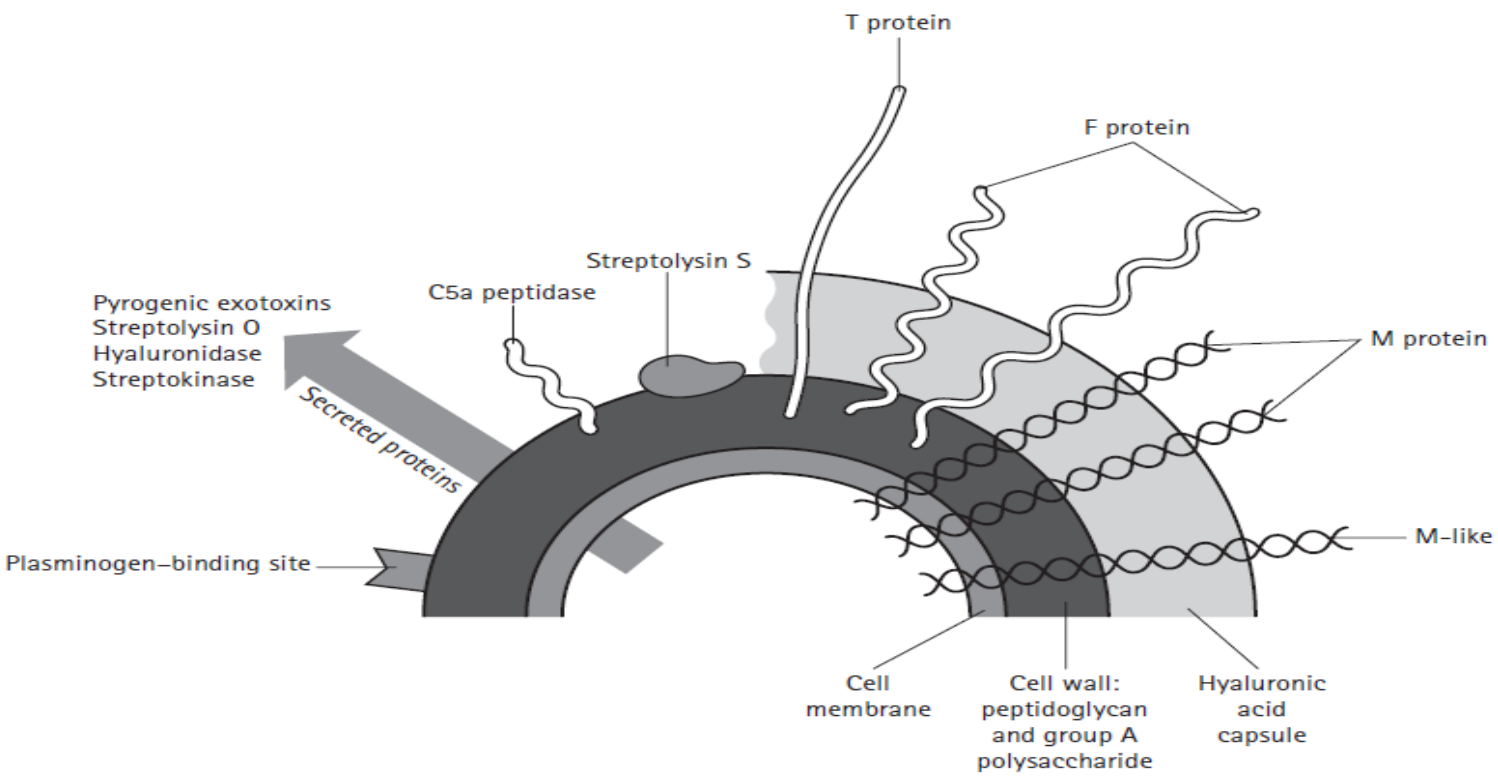

Figure. 1. Diagram showing the location of virulence-associated products of Str. pyogenes.

Source: (Thayer et al., 2008).

M protein: The streptococcal M protein is now probably one of the best-defined molecules among the Gram-positive bacterial virulence determinants. Its structure, function, immunochemistry, and method of antigenic variation are unique among known virulence molecules, and may serve as a model for certain microbial systems(Fischetti, 1989). M protein and are highly virulent in experimental animals(Lancefield, 1940; Wessels et al., 1991). M proteins is Surface protein that 
linked LPXTG motif and used for classification of S. pyogenes strains into M serotypes because of Nterminal hypervariable region that exhibits extensive sequence variability between strains. It is binds to complement control factors (Factor $\mathrm{H}$, factor $\mathrm{H}$-like protein (FHL-1), C4b-binding protein (C4BP)) and host proteins (fibrinogen) to prevent activation of the alternate complement pathway and impede phagocytosis. It seems to be important in adherence to Hep-2 cells in tissue culture and mediates adherence to skin keratinocytes via the attachment of the $\mathrm{C}$ repeat region to keratinocyte membrane cofactor CD46. Involve in the internalization process (zipper like mechanims). M proteins have been suggested to play a role in the generation of an inflammatory response by binding of fibrinogen, kininogen, or plasminogen(Carlssonet al., 2003; Herwald et al., 2004).

$\mathrm{M}$ protein has been considered to be the major surface component responsible for resistance of GAS to phagocytosis(Lancefield, 1962). The ability of Str. pyogenes to resist phagocytosis by polymorpho nuclear leucocytes is to a high degree due to the cell surface-exposed M protein. The M protein is anchored in the cytoplasmic membrane, spans the entire cell wall, and protrudes from the cell surface as fibrils. Acquired resistance to infection by Str. pyogenes is the result of antibodies in secretions and sera to the M protein molecule(Kilian, 2002).

Some strains produce two different $M$ proteins with anti-phagocytic activity and some, in addition, a structurally related M-like protein. All these proteins can bind various serum proteins of the host, including fibrinogen, plasminogen, albumin, $\operatorname{IgG}, \operatorname{IgA}$, the proteinase inhibitor $\alpha 2$-macroglobulin, and some regulatory factors from the complement system (factor $\mathrm{H}$ and $\mathrm{C} 4$ bbinding protein). As well as masking the bacterial surface with host proteins some of these affinities are probably responsible for the ability of $M$ proteins to resist phagocytosis. It is cytotoxic for neutrophils. Streptococcal M protein mimic those of mammalian muscle and connective tissue. More than 50 types of $S$. pyogenes $\mathrm{M}$ proteins have been identified on the basis of antigenic specificity. The $\mathrm{M}$ proteins of lower M-types (e.g., 1, 3, 5, 6, 14, 18, 19, and 24) are considered rheumatogenic since they contain antigenic epitopes related to heart muscle, and may lead to autoimmune rheumatic carditis (rheumatic fever) following an acute pharyngeal infection.Acute glomerulonephritis can follow streptococcal infection of the pharynx (pharyngitis-associated Acute glomerulonephritis e.g., 1, 4, 12, 25) or or the skin (pyoderma-associated AGN-mainly higher M types e.g., 2, 49, 55, 57, 59, 60, 61) is caused by nephritogenic strains thus, factor $\mathrm{H}$ is capable of destabilizing the important opsonin $\mathrm{C} 3 \mathrm{~b}$ when deposited on the bacterial surface. Likewise, the C4b-binding protein inhibits surface complement deposition by stimulating degradation of both $\mathrm{C} 4 \mathrm{~b}$ and $\mathrm{C} 3 \mathrm{~b}$ (https://microbeonline.com/virulencefactors-streptococcus-pyogenes-roles/).

SIC (streptococcal inhibitor of complement-mediated lysis): A hypervariable extracellular protein, with the amount of polymorphism far exceeding that present in any bacterial protein except those directly associated with antibiotic resistance. This variation may arise from pressure from the immune system that makes it expedient for the bacteria to change their surface antigens. Used to binds to the membrane insertion site on complement C5b67 and inhibits lysis of the bacteria, enhances survival of bacteria to avoid the intracellular environment by interfering with the ability of eukaryotic plasma membrane protein ezrin and possibly moesin, to bind actin and inhibits components of the mucosal innate response: lysozyme, secretory leucocyte proteinase inhibitor, human $\alpha$-defensin 1 and the cathelicidin LL-37, thus inhibits the variable antibacterial action against GAS(Frick et al., 2003; Hoe et al., 2002).

Lipoproteinase: This enzyme is also called opacity factor, as it induces opalescence in growth media containingserum. The exact biological significance is not known but there is a strong correlation between the production of this enzyme and particular $M$ types, and it is produced mainly by strains causing skin infections(Kilian, 2000).

\subsubsection{Exoenzyme}

Deoxyribonucleases (DNAases): At least four distinct forms of DNAases, designated A, B, C and D, are produced by Str. pyogenes. DNAase B is the most common form. The enzymes hydrolyse nucleic acids and may play a role as spreading factors by liquefying viscous exudates(Kilian, 2000). DNase B has been shown to be the same molecule as the streptococcal mitogenic factor (MF). It does not contribute significantly to the superantigenic activity of S. pyogenes when compared with other Species. Digesting DNA released from dead cells the enzyme reduces the viscosity of pus and allows the organism greater motility(Bisnoet al., 2003). 
Hyaluronidase (hylP; hylP; hylP): Hyaluronidase is widely assumed to facilitate the spread of the bacteria through tissues by breaking down hyaluronic acid, an important component of connective tissue. However, very few isolates of $S$. pyogenes are capable of secreting active hyaluronidase due to mutations in the gene that encode the enzyme. Moreover, the few isolates capable of secreting hyaluronidase do not appear to need it to spread through tissues or to cause skin lesions. Thus, the true role of hyaluronidase in pathogenesis, if any, remains unknown(Starr and Engleberg, 2006).It has been determined that the GAS HA capsule is structurally identical to mammalian hyaluronic acid, which is a known substrate for streptococcal hyaluronidase(Starr and Engleberg, 2006). Since hyaluronidases are enzymes that catalyze the breakdown of hyaluronic acid in the body, they may increase the permeability of tissue to fluids. Hyaluronidase in snake and insect venom is thought to function as a "spreading factor" by degrading host hyaluronic acid, thus allowing spread of toxin(Kreil, 1995).

GAS are capable of producing two types of hyaluronidase, a bacteriophage associated enzyme and an extracellular hyaluronidase that is secreted from the cell. Since the capsule of GAS is composed solely of hyaluronic acid, the hyaluronidase presumably benefits the phage by aiding in capsule penetration during its infection of or release from streptococci. It used to degradation of hyaluronic acid present in the ground substance of connective tissue to aid the streptococci in their spread. By cleaves the 1,4-glycosidic linkage between $\mathrm{N}$-acetyl-b-D-glucosamine and D-glucuronic acid residues in hyaluronan and catalyzes the release of unsaturated polysaccharides, with the disaccharide unit 2acetamido-2-deoxy-3- $O$-( $\beta$-D-gluco-4-enepyranosyluronic acid)-D-glucose being the main end product(Baker et al., 2002; Mylvaganam et al., 2000).

IdeS (IgG-degrading enzyme of $S$. pyogenes): It protects the bacteria from opsonizing IgG antibodies also binds to and block CD11b and can also block the activity of FcyIII (CD16), which is one of the receptors that recognize IgG. Blocking CR3 not only blocks phagocytosis mediated by $\mathrm{C} 3 \mathrm{~b}$, but also reduce antibody-mediated phagocytosis. It cleaves the heavy chain of $\operatorname{IgG}$ at glycine residue 237 , generating two stable Fab fragments and one Fc fragment(Lei et al., 2003).

SpeB (streptococcal pyrogenic exotoxin B): It is integrin-binding cysteine protease secreted in a zymogen form (40-kDa, 371 residues) and auto catalytically cleaved $\mathrm{N}$ terminal 118 residues to generate the mature proteinase. It used to facillitates bacterial dissemination and survival, as well as induces inflammation during $S$. pyogenes infections. It cleaves human proteins like fibrin, fibronectin and vitronectin, and matrix proteoglycans that involved in maintaining host tissue integrity. Thencleave human immunoglobins probably interfering with their opsonizing capacity then cleaves human IL-1 $\beta$ precursor to form bioactive IL-1 $\beta$.It used also for processes monocytic cell urokinase receptor, and releases active kinins from kininogen. The Interactions between SpeB and M protein are important for correct folding and maturation of the cysteine proteinase. The M protein is not only involved in the folding of SpeB, but is also a substrate for SpeB. The enzyme cleaves and releases fragments of $\mathrm{M}$ protein which have retained their affinity for different human plasma proteins. It activates host matrix metalloproteinase may contribute to the extensive soft tissue destruction(von Pawel-Rammingen and Björck, 2003).

\subsubsection{Immune Evasion}

C5a peptidase: The C5a peptidase, which is found also in human pathogenic strains of Str. agalactiae, is presented on the surface of all strains of Str. pyogenes. It specifically cleaves, and thereby inactivates, human $\mathrm{C} 5 \mathrm{a}$, one of the principal chemoattractants of phagocytic cells(Kilian, 2002). It is surface protein that linked LPTTN motif that used to increases dissemination of GAS. Specifically degrading the chemotactic complement factor C5a, generated by proteolytical cleavage of C5 during complement activation, thus, prevent neutrophil migration to the site of infection by reducing the concentration of $\mathrm{C} 5 \mathrm{a}$, which guides the neutrphils to their target(Anderson et al., 2002; Cunningham, 2000).

\subsubsection{Plasminogen Activator}

Streptokinase: Streptokinase, also known as fibrinolysin, is another spreading factor. It is expressed by all strains of Str. pyogenes and co-operates with a surface expressed plasminogen-binding site on the bacteria. Once host plasminogen is bound to the bacterial surface, it is activated to plasmin by streptokinase. Thus, in contrast to Staph. aureus, which aims at hiding behind a wall of coagulated plasma (fibrin), Str. pyogenes employs host plasmin to hinder build-up of fibrin barriers. As a result, 
soft tissue infections due to Str. pyogenes are more diffuse, and often rapidly spreading, in contrast to the well localized abscesses that typify staphylococcal infections(Kilian, 2000). Enzymatically activates plasminogen, a proteolytic enzyme, into plasmin, which in turn digests fibrin and other proteins (https://en.wikipedia.org/wiki/Streptococcus_pyogenes).

Streptokinase and staphylokinase share little sequence homology but their cystal structures have similar fold: $\beta$-grasp. They are used to promotes bacterial invasion of tissues. Like staphylokinase, streptokinase is not enzyme itself but form 1:1 complexes with plasminogen and plasmin, leading the changes in conformation and specificity of plasmin (ogen). Plasminogen, or plasmin can be recruited to the streptococcal cell surface by the M-like protein (PAM), the glyceraldehyde-3-phosphate dehydrogenase, $\alpha$-enolase. Streptokinase catalyses the plasminogen to plasmin. Plasmin is a broad spectrum serine protease that degrades fibrin and non-collagenous proteins of extracellular matrices and activates latent procollagenases(Lähteenmäki et al., 2001; Svensson et al., 2002).

\subsubsection{Toxin}

Streptolysins: Str. pyogenes produces two distinct haemolysins, termed streptolysins O (oxygenlabile) and S (serum-soluble), both of which lyse erythrocytes, polymorphonuclear leucocytes and platelets by forming pores in their cell membrane. Streptolysin O belongs to a family of haemolysins found in many pathogenic bacteria. Streptolysin O may play a role in the pathogenesis of poststreptococcal rheumatic fever. Streptolysin S is responsible for the $\alpha$-haemolysis around colonies on blood agar plates. It can also induce the release of lysosomal contents with subsequent cell death after engulfment by phagocytes. In contrast to streptolysin $\mathrm{O}$ it is not immunogenic(Greenwood et al., 2012).

Streptolysin O (SLO) is a pore-forming, cholesterol-dependent, oxygen-labile, thiol-activated cytotoxin. Similar types of hemolysins are produced by a variety of other pathogens, and the structure of SLO is similar to these other cholesterol-dependent cytolysins, but there are also some differences. One difference is in the binding of the cytolysins to cholesterol-rich membranes, where there is a structural difference in the membrane-binding interface between SLO and perfringolysin O(Ferretti et al., 2001). The SLO hemolysin is $69 \mathrm{kDa}$ in size, which is subject to $\mathrm{N}$-terminal cleavage by the cysteine proteinase(Pinkney et al., 1995). The hemolysin is produced with a 70-residue N-terminal region that is required for the translocation of another streptococcal product, the NAD-glycohydrolase (nga) into host cells (Pinkney et al., 1995); with slo and $n g a$ being co-transcribed (Madden et al., 2001).

Streptolysin $\mathrm{O}$ pore formation occurs in stages, including cholesterol-dependent binding of monomeric forms to the cell membrane, followed by oligomerization, which results in the development of pores (Bhakdi et al., 1985; Bhakdi and Tranum-Jensen, 1985). In addition to cholesterol, the membrane-binding domain of SLO also implicates a glycan (galactose) receptor involvement in binding and pore formation (Mozola and Caparon, 2015; Shewell et al., 2014). These pores result in disruption of the integrity of host cell membranes and induce apoptosis (Timmeret al., 2009). An alternate pathway utilized by $S$. pyogenes adhering to cells does not involve the galactose receptor, but an unknown receptor that associates with the streptococcal NAD-glycohydrolase (NADase, Nga, or SPN); this results in translocation of the NADase and orients the SLO, which allows for pore formation(Mozola and Caparon, 2015). Streptolysin O has also been shown to induce intracellular $\mathrm{Ca}^{2+}$ oscillations that result from the depletion of intracellular stores and activation of store-operated $\mathrm{Ca}^{2+}$ in host cells, the mechanisms of which remain unknown (Usmani et al., 2012).

SLS (Streptolysin S): It isOxygen stable, most potent cytotoxin, Not immunogenic and unstable polypeptide bounds to carrier molecules, such as serum albumin, RNA core, or lipoteichoic acid, responsible for the $\beta$-hemolysis surrounding colonies of GAS grown on blood agar plates and SagA serves as SLS toxin precursor and eight additional genes in an operon is required for toxin maturation and export. pro-SLS is converted into an active cytolysin by the actions of SagBCD, a trimeric oxazole/thiazolesynthetase.It is SLS lyses a wide variety of eukaryotic cells, including myocardial cells, kidney cells, platelets, lymphocytes, and neutrophils(Mitchell, 2003).

Spes(streptococcal pyrogenic exotoxins)(Erythrogenic Toxins): Most strains of Str. Pyogenes produce one or more toxins that are called pyrogenic exotoxins because of their ability to induce fever. From the large number of extracellular products of group A streptococci, only the erythrogenic toxins (pyrogenic exotoxins) and the hemolysins (cytolysins) appear to have toxic properties. Three, SPE A, 
SPE B and SPE C, have been extensively characterized,but there are several others. Purified SPE A causes death when injected into rabbits, and is the most toxic of the three, but SPE B also causes myocardial necrosis and death in experimental animals. The genes for SPE A and SPE C are transmitted between strains by bacteriophage.. Unlike SPE A and SPE C, all strains of Str. pyogenesproduce SPE B, which is a potent cysteine proteinasecapable of cleaving many host proteins(Kilian, 2000). Two prototypical streptococcal superantigens, SPE A and SPE C are both encoded on functional phage. Crystal structure analyses have shown that superantigens have several conserved features, including an $\mathrm{N}$-terminal $\beta$-barrel domain and a $\mathrm{C}$-terminal zinc-binding motif, these zinc molecules are thought to mediate binding to class II molecules(Proftet al., 2003).
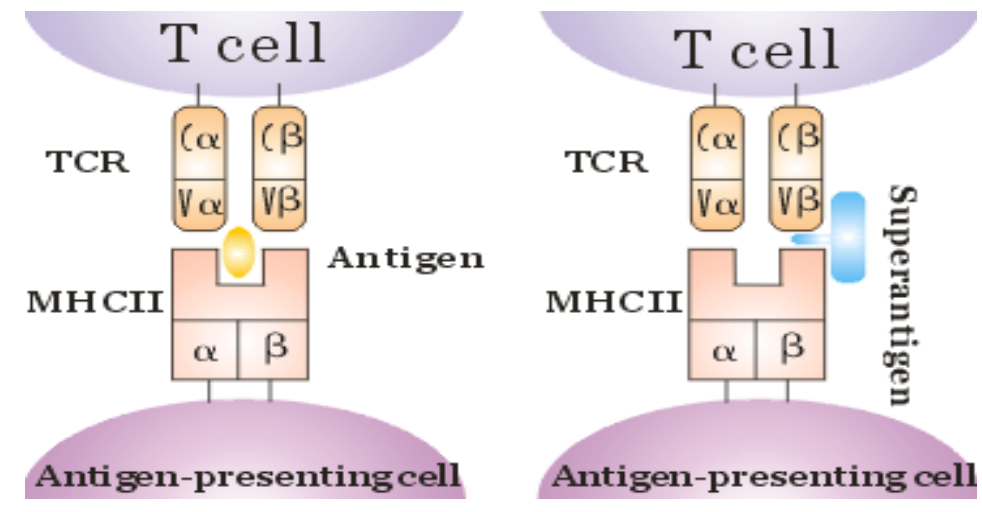

Figure.2. T cell activation by a conventional peptide antigen/by superantigenic toxin Source:(Tripp et al., 2003).

Superantigen:A family of molecules that share the ability to activate large populations of $\mathrm{T}$ lymphocytes through co-ligation between major histocompatibility complex (MHC) class II molecules on antigen-presenting cells and the variable portion of the T-cell antigen receptor $\beta$ chain; the patten of $\mathrm{V} \beta$ activation is specific for each of these superantigens. The best characterised are staphylococcal enterotoxins and the streptococcal pyrogenic exotoxins. It is used to associate with streptococcal toxic shock syndrome and streptococcal scarlet fever. May play a role in autoimmune responses in streptococcal sequelae(Llewelyn and Cohen, 2002).

Streptococcal chemokine protease: The affected tissue of patients with severe cases of necrotizing fasciitis are devoid of neutrophils(Kreil, 1995). The serine protease ScpC, which is released by $S$. pyogenes, is responsible for preventing the migration of neutrophils to the spreading infection. ScpC degrades the chemokine IL-8, which would otherwise attract neutrophils to the site of infection(Hidalgo-Grass et al., 2006; Ji et al., 1996).

\subsection{Major virulence factors in Str. pneumoniae}

\subsubsection{Adherence}

CbpA/PspC(choline-binding protein)Also known as PspC, SpsA, Hic (factor H-binding inhibitor of complement) or surface protein: choline-binding protein). It mediate adherence to sialic acid and lacto-N-neotetraose ligands present on cytokine-activated epithelial cells. It specifically binds the secretory component of human secretory immunoglobulin $\mathrm{A}$, human factor $\mathrm{H}$, and complement component $\mathrm{C} 3$. It is also involved in immune-cell recruitment and chemotaxis by stimulating the production of IL-8 from pulmonary epithelial cells. Also interacts with the human polymeric immunoglobulin receptor (pIgR), pIgR domain D3 and D4 together are necessary and sufficient for the ligand-binding activity. The poly-immunglobulin receptor (pIgR) of mucosal epithelial cells mediates the transport of $\mathrm{pIgA}$ across polarized epithelial cells, resulting in release of secretory component (SC), either free or bound covalently to $\operatorname{IgA}$. A hexapeptide motif of CbpA has been shown to interact in a human specific manner with the SC/pIgR(Lang and Palmer, 2003).

CBPs (Choline binding proteins): It is surface protein: choline-binding. It used to $\mathrm{CbpD}, \mathrm{CbpE}$, $\mathrm{CbpG}$, LytB and LytC play a role in adhesion and colonization of the nasopharynx (Lang and Palmer, 2003). Pneumococcus is known to require choline-binding protein A (CbpA) to adhere to the BBB in vitro(Ring et al., 1998) and to cause meningitis in vivo(Orihuela et al., 2003). Using CbpA as bait, we identified $37 / 67-\mathrm{kDa}$ LR as a ligand from an $\mathrm{rBCEC}_{6}$ lysate by affinity chromatography with matrixassisted laser desorption/ionization time-of-flight (MALDI-TOF) analysis. There is finding was 
confirmed by reactivity of the band with anti-LR antibody in immunoblot experiments (data not shown) and by coimmunoprecipitation of endothelial LR with rCbpA(Orihuela et al., 2009).

PavA (pneumococcal adherence and virulence factor A): Pneumococcal adherence and virulence factor A (PavA) is displayed to the cell outer surface of Streptococcus pneumoniae and mediates pneumococcal binding to immobilized fibronectin. PavA, which lacks a typical gram-positive signal sequence and cell surface anchorage motif, is essential for pneumococcal virulence in a mouse infection model of septicemia. In this report the impact of PavA on pneumococcal adhesion to and invasion of eukaryotic cells and on experimental pneumococcal meningitis was investigated.The pneumococcal cell surface protein PavA is a virulence factor associated with adherence and invasion in vitro.It acts directly as a fibronectin adhesion and affects pneumococcal colonization by modulating expression or function of important virulence determinants of S. pneumoniae(Kadiogluet al., 2010; Pracht et al., 2005).

PavB (Pneumococcal adhesion and virulence factor B): Pneumococcaladherence and virulence factor B (PavB) and pneumococcal surface protein C (PspC) are key players for the interaction of Streptococcus pneumoniae with matricellular hTSP-1. PavB and PspC are pneumococcal surfaceexposed adhesins and virulence factors exhibiting repetitive sequences in their core structure. Heterologously expressed fragments of PavB and PspC containing repetitive structures exhibit hTSP1 binding activity as shown by ELISA and surface plasmon resonance studies. Binding of hTSP-1 is charge-dependent and inhibited by heparin. Importantly, the deficiency in PavB and PspC reduces the recruitment of soluble hTSP-1 by pneumococci and decreases hTSP-1-mediated pneumococcal adherence to human epithelial cells. Platelet activation assays suggested that PavB and PspC are not involved in the activation of purified human platelets by pneumococci. In conclusion, this study indicates a pivotal role of PavB and PspC for pneumococcal recruitment of soluble hTSP-1 to the bacterial surface and binding of pneumococci to host cell-bound hTSP-1 during adhesion.A surfaceexposed adhesin, which contributes to pneumococcal colonization and infections of the respiratory airways(Binskeret al., 2015).

PfbA (Plasmin and fibronectin-binding protein $\mathbf{A}$ ): $\mathrm{PfbA}$ is a surface adhesin and invasin of Streptococcus pneumoniae that binds to human fibronectin and plasminogen of the host extracellular matrix. It is a virulence factor for its pathogenesis. The crystal structure of recombinant PfbA150-607 from S. pneumoniae strain R6, was determined using multiwavelength anomalous dispersion (MAD) method and refined to $1.90 \AA$ resolution. The structure of $\mathrm{rPfbA150-607}$ revealed that residues Thr150 to Lys570 form a rigid parallel beta helix, followed by a short disordered region (571-607) that consists of beta hairpins. The structural organization of the beta helix resembles that of polysaccharide-modifying enzymes.It is a surface adhesin and invasin that binds to human fibronectin and plasminogen of the host extracellular matrix(Beulinet al., 2014).

PI-1:Numerous pili or fimbriae are essential virulence factors and protective antigens in Gramnegative bacteria, where they are involved in adhesion of the bacteria to eukaryotic cells (Merz and So, 2000). In Gram-positive bacteria, pili have been described in Corynbacteriumdiphtheriae, where they are formed by covalent polymerization of pilin subunits catalyzed by particular sortase enzymes(Ton-That and Schneewind, 2003). Pilus-like structures have also been detected in some other Gram-positive bacteria(Ton-That and Schneewind, 2004); however, very little is known about their function, and they have not been described in any of the most important species of Streptococcus that are pathogenic to humans: GBS, Group A Streptococcus, and Streptococcus pneumoniae(Lauer et al., 2005).

Pili are a classical example of cell surface proteins in Gram-positive bacteria. These filamentous protein structures are often involved in adhering to and invading host tissue sites during infection. Pili are typically composed of a major subunit, called pilin, and one or more minor subunits, which are usually assembled sequentially using specialized sortases. Pathogens that are known to utilize pili during infection include Streptococcus pneumoniae, Streptococcus pyogenes, and $S$. aureus(Hendrickxet al., 2011; Telford et al., 2006). Pili are encoded by the rlrA pathogenicity islet, which carries genes forthree pilin proteins (the major pilin $\operatorname{RrgB}$ and two minor pilins, RrgA and $\mathrm{RrgC}, \mathrm{RrgA}$ is the tip adhesin) as well as three sortases. Play important roles in host tissue colonization and pathogenesis by enhancing adherence to host cells, recognizing the extracellular matrix, and manipulate the host inflammatory response(Orrskoget al., 2013; Pointon et al., 2010). 
PI-2: The type PI-2 streptococcal pilus presents in a number of invasive pneumococcal serotypes and consists of repeated units of a single protein, PitB, whose covalent association is catalyzed by cognate sortase SrtG-1 and partner protein SipA. Used to mediates host cell adhesion(Shaik et al., 2015).

\subsubsection{Antiphagocytosis}

Capsule: Ninety different capsule types have been identified andeach has a structurally distinct capsule, composed of repeating oligosaccharide units joined by glycosidic linkages. Resistant to complement deposition and masks cell wall-associated complement from being recognized by the complement receptors on phagocytes(Kadiogluet al., 2002).

\subsubsection{Complement Resistance}

PspA (pneumococcal surface protein A): It is surface protein and choline binding protein. It inhibits complement activation and reduces the effectiveness of complement receptor-mediated clearance mechanisms by preventing the deposition of $\mathrm{C} 3 \mathrm{~b}$ on the cell surface. Binds to lactoferrin, the iron starage glycoprotein predominantly located in mucosal secretions, may be involved in iron acquisition(Ren et al., 2004).

\subsubsection{Exoenzyme}

Hyaluronatelyase: -Streptococcus pneumoniae hyaluronatelyase is a surface enzyme of this Grampositive bacterium. The enzyme degrades hyaluronan and chondroitin/chondroitin sulfates by cleaving the beta1, 4-glycosidic linkage between the glycan units of these polymeric substrates. This degradation helps spreading of this bacterial organism throughout the host tissues and facilitates the disease process caused by pneumococci. The mechanism of this degradative process is based on betaelimination, is termed proton acceptance and donation, and involves selected residues of a welldefined catalytic site of the enzyme. The degradation of hyaluronan alone is thought to proceed through a processive mode of action. The structures of complexes between the enzyme and chondroitin as well as chondroitin sulfate disaccharides allowed for the first detailed insights into these interactions and the mechanism of action on chondroitins. This degradation of chondroitin/chondroitin sulfates is nonprocessive and is selective for the chondroitin sulfates only with certain sulfation patterns. Chondroitin sulfation at the 4-position on the nonreducing site of the linkage to be cleaved or 2-sulfation prevent degradation due to steric clashes with the enzyme. Facilitates tissue invasion by breaking down the extracellular matrix (ECM) components(Rigden and Jedrzejas, 2003).

\subsubsection{IgAl Protease}

IgA, the major class of Ig in secretions, classically functions by interfering with microbial attachment to host tissues. Many mucosal pathogens, including Streptococcus pneumoniae, express an IgA1 protease that may circumvent the protective effects of this Ig subclass. Because these proteases are specific for human IgA1, we generated human mAbs to the major surface antigen of the pneumococcus, its capsular polysaccharide, and tested their effect in a colonization model of bacterial adherence to respiratory epithelial cells in culture. Rather than inhibiting adherence, type-specific IgA1 markedly enhanced bacterial attachment to host cells, but only when cleaved by IgA1 protease. Neither antibodies of protease-insensitive subclasses (IgA2 and $\operatorname{IgG}$ ) nor those directed against heterologous capsules had such activity. The adherence-promoting properties of cleaved antibodies correlated with the cationic characteristics of their variable segments, suggesting that bound Fab fragments may neutralize the inhibitory effect of negatively charged capsules on adhesive interaction with host cells. Coating of pneumococci with anticapsular polysaccharide antibody unmasked the bacterial phosphorylcholine ligand, allowing for increased adherence mediated by binding to the platelet activating factor receptor on epithelial cells. In addition, our findings provide evidence for a novel function of bacterial IgA1 proteases. These enzymes may enable pathogens to subvert the antigen specificity of the humoral immune response to facilitate adhesive interactions and persistence on the mucosal surface(Weiser et al., 2003).

The $\mathrm{ZmpC}$ zinc metalloproteinase of Streptococcus pneumoniae, annotated in the type 4 genome as SP0071, was found to cleave human matrix metalloproteinase 9 (MMP-9). The previously described IgA protease activity was confirmed to be specifically linked to the IgA1-protease/SP1154 zinc metalloproteinase. MMP-9 is a protease cleaving extracellular matrix gelatin and collagen and is activated by proteolytic cleavage like most proteases. MMP-9 is a human protease and is involved in a 
variety of physiological and pathological matrix degrading processes, including tissue invasion of metastases and opening of the blood-brain barrier. While TIGR4 (serotype 4) and G54 (serotype 19) pneumococcal genome strains have a highly conserved copy of zmpC, the genome of R6 (a derivative of serotype $2 \mathrm{D} 39$ strain) lacks $\mathrm{zmpC}$. Both the analysis for $\mathrm{zmpC}$ presence and MMP-9 cleavage activity in various pneumococcal strains showed correlation of $\mathrm{ZmpC}$ with MMP-9 cleavage activity. When assaying clinical isolates of $\mathrm{S}$. pneumoniae, the $\mathrm{zmpC}$ gene was not found in any of the nasal and conjunctival swab isolates, but it was present in 1 out of 13 meningitis isolates and in 6 out of 11 pneumonia isolates. In a murine pneumonia model, infection with a zmpC-mutant reduced mortality at 3-4 days post-infection by $75 \%$, when compared with infection with wild-type strains. These data indicate that the ZmpC pneumococcal protease may play a role in pneumococcal virulence and pathogenicity in the lung(Oggioni et al., 2003).

\subsubsection{Manganese uptake}

PsaA (pneumococcal surface antigen A): Surface protein: lipid-attached. AdcABC is another ABC transporter for $\mathrm{Zn}^{2+}$ uptake. Key function is the transport of $\mathrm{Mn}^{2+}$ and $\mathrm{Zn}^{2+}$ into the cytoplasm of the bacteria. psaA mutants show marked impact on the capacity to colonize and increased susceptibility to oxidative damage(McAllister et al., 2004).

\subsubsection{Protease}

Autolysin: It is surface protein and choline-binding proteins anchored to the cell surface by a noncovalent interaction of a repeat region at the C-terminal with the phosphorylcholine of the cell wall. Attachment of the enzyme to the choline of the $S$. pneumoniae cell wall teichoic acid is essential for the lytic activity of the enzyme. $N$-acetylmuramoyl-L-alanine amidase: degrading the peptidoglycan backbone of the bacteria, leading to the release of the component of cell wall shown to be highly inflammatory and the release of cytoplasmic bacterial proteins including bacterial virulence factors such as pneumolysin(De Las Rivas et al., 2002).

Neuraminidase:It cause significant damage to host cell glycans, change the glycosylation patterns of the host and probably exposes more of the host cell surface, which may reveal surface receptors for possible interaction with the bacteria, contributing to increased adhesion. Cleaves terminal sialic acid from cell surface glycans such as mucin, glycolypids, and glycoproteins. Acts on three sialyl-linkage classes of substrate: $\alpha 2-3$ and $\alpha 2-6$ to galactose, and $\alpha 2-6$ to N-acetyl galactosamine(Jedrzejas, 2001).

\subsubsection{Toxin}

Pneumolysin: It shares amino acid homology with similar hemolysins such as SLO, LLO, but pneumolysin is a cytoplasmic protein rather than a secreted protein. Multi-function enzyme includes: forming pore in the host cell membranes, inflammatory and proapoptotic effects, stimulating the production of inflammatory mediators such as TNF- $\alpha$, IL-1 $\beta$, nitric oxide, IL- 8 , and prostaglandins and leukotrienes, inhibiting nonspecific defences like inducing ciliary stasis, evasion of immune system likeantiphagocytosis and interferes with the complement pathway. A cytoplasmic cholesteroldependent cytolysin that is released due to the action of surface pneumococcal autolysin, the mode of action is based on binding to the host cell cytoplasmic membrane cholesterol, inserting into the targeted membranes and forming large oligomeric arc and ring structures, knowns as pores, disrupt and damage the cell membrane allowing the contents of the cell to spill out. May bind to Toll-like receptor 4 (TLR4) to induce inflammatory events(Cockeranet al., 2002a, 2002b; Malley et al., 2003; Stringaris et al., 2002).

Hydrogen peroxide (H2O2): The pneumococcus also produces copious amounts of hydrogen peroxide ( $\mathrm{H} 2 \mathrm{O} 2)$ through the action of the enzyme pyruvate oxidase, reaching low millimolar concentrations in bacteriological culture medium. $\mathrm{H} 2 \mathrm{O} 2$ is an indiscrimate, cell-permeable oxidant, which is toxic for both eukaryotic and prokaryotic cells. Importantly, $\mathrm{H} 2 \mathrm{O} 2$ is cytotoxic for ciliated respiratory epithelium, causing ciliary slowing and epithelial damage, favouring adhesion to, and invasion of, epithelial cells by the pneumococcus(Feldman et al., 2002). Although potentially suicidal for the pneumococcus, which does not produce catalase, $\mathrm{H} 2 \mathrm{O} 2$ also appears to induce biofilm formation, which is likely to favour persistence of the microbial pathogen in the respiratory tract(Hall-Stoodley and Stoodley, 2009). Antagonism of the mucociliary escalator by $\mathrm{H} 2 \mathrm{O} 2$, acting in concert with the protein virulence factors pneumolysin and hyaluronidase as described below, 6,7 
facilitates the attachment of the pneumococcus to airway epithelium via the binding of a third nonprotein virulence factor, phosphorylcholine on the pneumococcus, to the platelet-activating factor (PAF) receptor on the epithelium(Kadioglu et al., 2008; Preston and Dockrell, 2008).

\subsubsection{Biofilm}

The role of biofilm in microbial colonisation/persistence is important, as this is a common strategy utilised by the pneumococcus to evade host defences. Biofilm is a hydrated, self-generated polymer matrix in which microbial pathogens are effectively insulated against the cellular and humoral defence mechanisms of the host. Biofilm also restricts the penetration of antibiotics, favouring antibiotic resistance. Importantly in the pneumococcus, by the mechanisms described below, adhere to and invade airway epithelium. Biofilm-encased aggregates, in which both pathogens may coexist, either attached to the epithelial surface, or sequestered intracellularly, providing a potential mechanism for bacterial persistence(Hall-Stoodley and Stoodley, 2009). Concealed in biofilm, in which they communicate by quorum sensing mechanisms, these microbial pathogens can re-emerge at times when host defences are transiently or irreversibly compromised, as may occur during infection with influenza virus/respiratory syncitial virus or HIV-1, respectively(Anderson and Feldman, 2011).

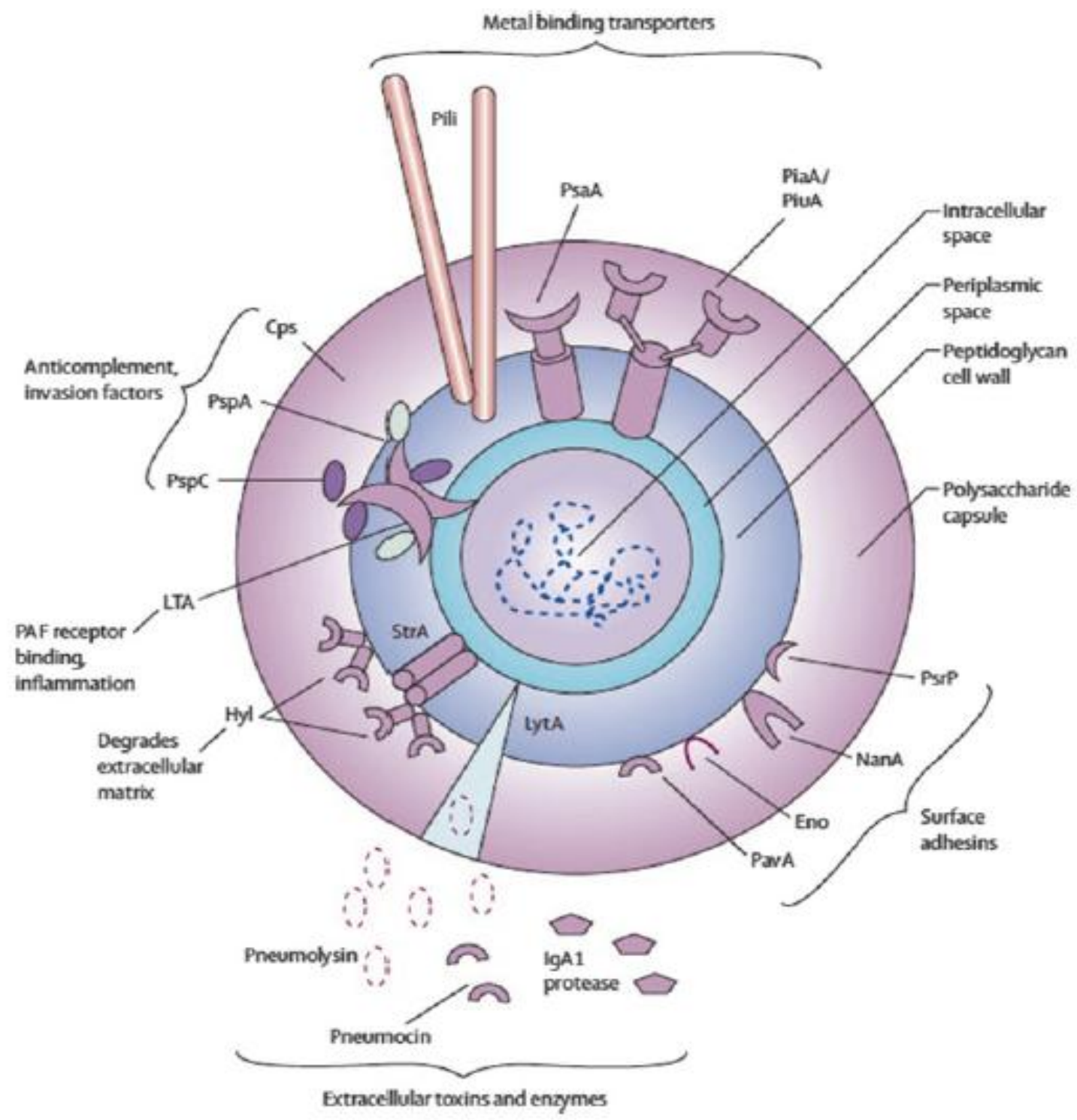

Figure. 3. S. pneumoniae virulence factors

Source: (van der Poll and Opal, 2009). 
Table 1. Key non-protein and protein virulence factors of the pneumococcus

\begin{tabular}{|c|c|}
\hline Factor & Activity \\
\hline Polysaccharide capsule & $\begin{array}{l}\text { Prevents binding to mucopolysaccharides, } \\
\text { antiphagocytic. }\end{array}$ \\
\hline Hydrogen peroxide & Cytotoxic, impairs mucociliary escalator function. \\
\hline Phosphorylcholine & Epithelial adhesin. \\
\hline Pneumolysin & $\begin{array}{l}\text { Cytotoxic, impairs mucociliary escalator function, } \\
\text { apoptosis of dendritic cells, complement consumption, } \\
\text { proinflammatory. }\end{array}$ \\
\hline Zinc metalloproteinase & Cleaves secretory $\lg A$. \\
\hline Hyaluronidase & $\begin{array}{l}\text { Potentiates the inhibitory effects of hydrogen peroxide } \\
\text { and pneumolysin on mucociliary escalator function. }\end{array}$ \\
\hline PsaA & Epithelial adhesin. \\
\hline PspA, PspC & $\begin{array}{l}\text { Epithelial adhesin, interference with complement } \\
\text { activation. }\end{array}$ \\
\hline PfbB & Epithelial adhesin. \\
\hline
\end{tabular}

Source : (Anderson and Feldman, 2011)

\subsection{Major virulence factors in S. agalactiae}

Str. agalactiaeproduces several virulence factors, including haemolysins, capsule polysaccharide, C5a peptidase (only human pathogenic strains), hyaluronidase (not all strains), and various surface proteins that bind human IgA and serve as adhesins. Nine different types of the capsular polysaccharide have been identified (Ia, Ib, and II-VIII). The serotype most frequently associated with neonatal infections is type III, whereas infections in adults are more evenly distributed over the different serotypes. Among the haemolysins produced by Str. agalactiae, one, known as the CAMP factor (so-called because it was originally described by Christie, Atkins and Munch-Petersen), plays an important role in the recognition of this species in the laboratory(Kilian, 2000).

\subsubsection{Adherence}

FbsA: Streptococcal surface protein, contains long tandem repeating elements, the number of repeats vary significantly between different strains, C-terminal domains LPXTGX, associated with attachment to the cell wall.It used to fibrinogen-binding protein, the fibrinogen-binding region is located in the repeat region of FbsA(Johnson, 2018b; Pietrocola et al., 2006; Rosenau et al., 2007).

FbsB(Fg-binding surface protein B): N-terminal region of FbsB have been shown to bind to human Fibrinogen, while the C-terminal region of $\mathrm{FbsB}$ has been speculated to bind to bovine FibrinogenLmb(Devi and Ponnuraj, 2010; Gutekunst et al., 2004; Rosenau et al., 2007).

Lmb (Laminin-binding protein): Lmb is an extracellular protein thatwas first identified in $S$. agalactiae. Homologs of this protein were reported in S. pyogenes and S. pneumonia and termed Lbp and AdcAII, respectively. It is $34 \mathrm{kDa}$ lipoprotein mediates the attachment to human laminin, a major component of the basement membrane, which may be essential for the bacterial colonization. Also important for the invasion of human brain endothelial cells(Ragunathanet al., 2013; Spellerberg et al., 1999).

PI-1 (pilus island 1): The genes encoding pili are located within 2 distinct loci, denoted pilus islands 1 and 2 (PI-1 and PI-2), the latter having 2 allelic variants (PI-2a and PI-2b).Each pilus island (PI) comprises 3 genes that encode structural proteins with a characteristic LPXTG anchoring motif recognised by sortasetranspeptidases: It has backbone $(\mathrm{Bkb})$ subunit (forming the polymeric shaft of the pilus), ancillary subunit 1 (An1, the functional tip), and ancillary subunit 2 (An2, the C-terminal anchor following attachment to peptidoglycan in the cell wall by sortase A). Mediating cell 
attachment, promoting the invasion of human endothelial cells and may facilitate paracellular translocation across the epithelial barrier(Brittan and Nobbs, 2015; Rosini et al., 2006; Sharma et al., 2013; Vengadesan et al., 2011).

PI-2a (pilus island 2a): Mediating cell attachment, promoting the invasion of human endothelial cells and may facilitate paracellular translocation across the epithelial barrier. Promoting biofilm formation(Maiseyet al., 2007; Rosini et al., 2006).

\subsubsection{Antiphagocytosis}

$\boldsymbol{\beta}$-C protein:It binds the $\mathrm{Fc}$ portion of serum $\operatorname{IgA}$ and the complement inhibitor factor $\mathrm{H}$, may therefore play a role in preventing opsonophagocytosis(Lang and Palmer, 2003).Capsule: Inhibits the binding of the activated complement factor $\mathrm{C} 3 \mathrm{~b}$ to the surface of $S$. agalactiae, preventing the activation of the alternative complement pathway and inhibits complement-mediated opsonophagocytosis(Lang and Palmer, 2003).

\subsubsection{Exoenzyme}

Hyaluronatelyase: It facilitates spread of bacteria by breaking down the hyalurone polymers present in the extracellular matrices of the host. The GBS hyaluronatelyase also has limited specificity for achondroitin sulphate and cleaves the chain at unsulphated sites. This action may facilitate deep tissue penetration during infection(Lin et al., 1994).

\subsubsection{Immune evasion}

C5a peptidase: All group A streptococcal serotypes and group B, C, and G streptococci of human origin produce the C5a peptidase. The enzyme is highly conserved. Cleaves C5a, the major neutrophil chemoattractant produced by activation of the complement cascade, causing an impaired recruitment to sites of infection. Functions as an invasion and Fibronectin binding proteins(Bohnsacket al., 1991; Cleary et al., 1991).

\subsubsection{Invasion}

$\boldsymbol{\alpha}-\mathbf{C}$ protein: Interacts with host cell glycosaminoglycan (GAG) and mediates bacterial internalization by a mechanism that involves Rho GTPase-dependent actin rearrangements(Bolduc et al., 2002).

\subsection{6. $\underline{\text { Toxin }}$}

及-haemolysin/cytolysin: Lyses not only red blood cells but a broad range of eukaryotic cell types. Surface associated protein that can be extracted from the cells by non-ionic detergent, starch or albumin. Forms pores in cell membrane. Proinflammatory effects and it inducing apoptosis, promoting cellular invasion, triggering iNOS and cytokine release(Doran et al., 2002; Nizet, 2002).CAMP factor:Forms pores in cell membrane by oligomerization. Binds to the Fc fragments of human IgG and $\operatorname{IgM}($ Lang and Palmer, 2003).

\section{SECRETION SYSTEM}

Bacterial pathogens utilize a multitude of methods to invade mammalian hosts, damage tissue sites, and thwart the immune system from responding. One essential component of these strategies for many bacterial pathogens is the secretion of proteins across phospholipid membranes. Secreted proteins can play many roles in promoting bacterial virulence, from enhancing attachment to eukaryotic cells, to scavenging resources in an environmental niche, to directly intoxicating target cells and disrupting their functions. Many pathogens use dedicated protein secretion systems to secrete virulence factors from the cytosol of the bacteria into host cells or the host environment. In general, bacterial protein secretion apparatuses can be divided into different classes, based on their structures, functions, and specificity. Some systems are conserved in all classes of bacteria and secrete a broad array of substrates, while others are only found in a small number of bacterial species and/or are specific to only one or a few proteins(Green and Mecsas, 2016).

A growing number of pathogens are being found to possess specialized secretion systems which they use in various ways to subvert host defenses. Type IV secretion system (T4SS) is one of versatile secretion systems essential for the virulence and even survival of some bacteria species, and they enable the secretion of protein and DNA substrates across the cell envelope. T4SS was once believed to be present only in Gram-negative bacteria. There is evidence of a new subclass of T4SS, Type-IVC secretion system and indicate its common existence in the Gram-positive bacterial 
genus Streptococcus (Cascales and Christie, 2003; Fronzes et al., 2009; Waksman and Fronzes, 2010).

\subsection{Sec system (SecY2A2) in Streptococcus pneumoniae}

Like Gram-negative organisms, Gram-positive bacteria employ both the Tat and Sec pathways to transport proteins across the cytoplasmic membrane. However, in many cases, this transport is not sufficient to deliver proteins to their final destinations. A number of Streptococci and Staphylococci express a second Sec secretion system called a Sec or SecA2-SecY2. Accessory Sec systems dedicated to exporting a subset of proteins. In pathogens, the accessory Sec systems are linked to virulence. SecA2 might function in a similar manner to the canonical SecA by delivering precursor proteins to a translocase and energizing export across the membrane. These systems not only contain SecA2, but also have other proteins that serve to transport SecA2 substrates, including SecY2 and at least three accessory Sec transport proteins. a Sec systems typically transport large, highly glycosylated cell-wall anchor proteins with serine-rich repeats(SRR) (Mistou et al., 2009; Siboo et al., 2008).

SRR (serine-rich repeats) glycosylated proteins function as adhesins in a number of Streptococcus and Staphylococcus species, and can contribute to virulence in these pathogens. In contrast to bacteria that only express SecA1, bacteria expressing aSec are thought to transport substrates through a channel called SecY2. SecY2 lacks the cytoplasmic loops in SecY that normally interact with SecA1, and therefore SecA1 bound substrates are unlikely to interact with SecY2 transporters (Bensing et al., 2014). In addition, there are three accessory proteins in this system, whose roles are not yet understood, although they are essential for secretion of these glycoproteins(Seepersaudet al., 2010). All of these proteins localize to the membrane and cytosol and may help deliver the SecA2-substrate complex to SecY2, open the pore, assist in transport of the substrate, and participate in complete glycosylation of these substrates(Green and Mecsas, 2016).

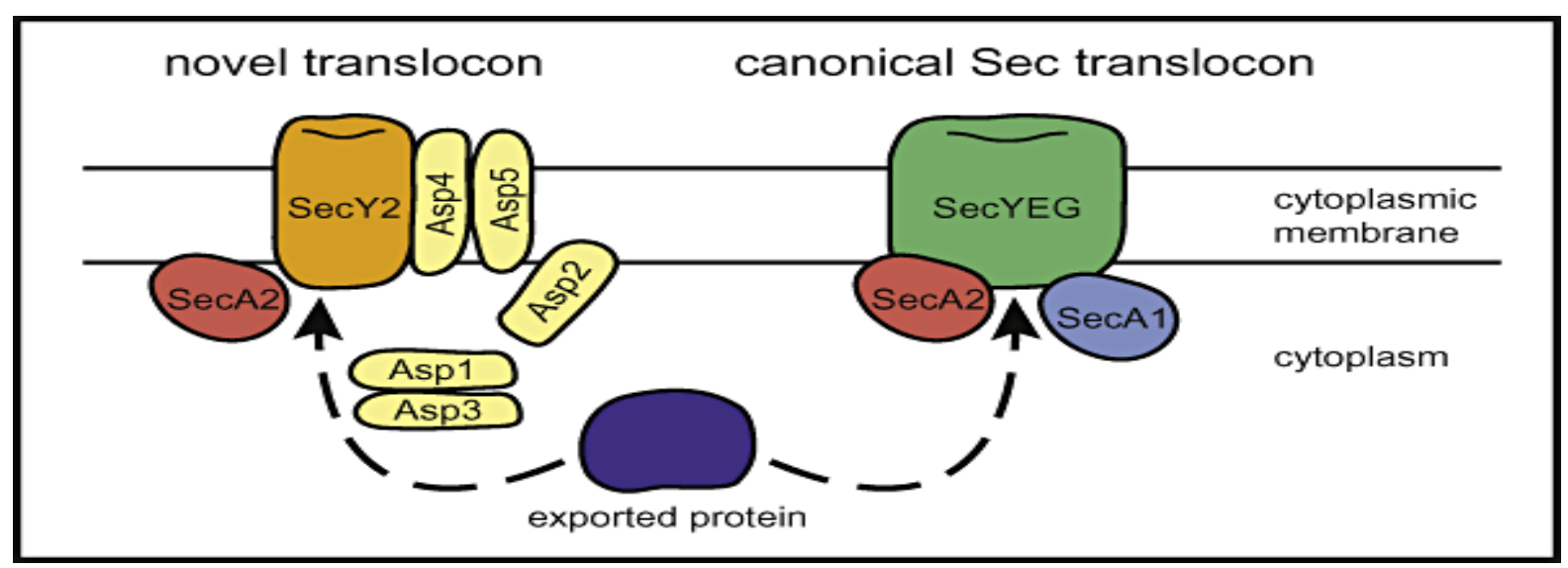

Figure 4. Models for SecA2-dependent export

Source: (Chen et al., 2006).

Models for SecA2-dependent export. In the various accessory Sec systems, a SecA2-exported protein (shown in blue) might be exported either through a novel translocon or the canonical SecA1/SecYEGtranslocon with the assistance of SecA2. The example of a novel translocon is modelled on the SecA2/SecY2 system of $S$. gordonii, which is a candidate for this type of pathway(Chen et al., 2006).

\subsection{Injectosomes}

One secretion apparatus which is proposed to be functionally analogous to the T4SSs and T3SSs of Gram-negative bacteria. This model of protein secretion has been observed in the Gram-positive pathogen Streptococcus pyogenes, which injects at least one virulence factor, NAD glycohydrolase (SPN), into the cytoplasm of keratinocytes by this mechanism(Ghosh and Caparon, 2006; Mazmanian et al., 1999). In order to create the pore required for SPN translocation, another protein, SLO, is first secreted via the Sec pathway. SLO is a member of a class of toxins called cholesterol-dependent cytolysins (CDCs), which bind cholesterol on the surface of eukaryotic cells and insert into their membranes, creating pores(Tweten, 2005). Following pore formation by SLO, SPN is translocated across the plasma membrane by Sec, and into the eukaryotic cell through the pore(Madden et al., 
2001). Once it reaches the cytosol of host cells, SPN cleaves the glycosidic bond of $\beta-\mathrm{NAD}^{+}$to produce nicotinamide and ADP-ribose, a potent second messenger thereby disrupting normal cell functions. For this reason, SPN serves as a major virulence factor for Streptococcus pyogenes, particularly during severe infections with this bacterium(Ghosh et al., 2010). Interestingly, there is some evidence that SPN translocation is not simply the result of diffusion of effectors through the pore(Madden et al., 2001). Rather, some have speculated that a protected channel is formed between the bacterium and the translocation apparatus, similar to the T3SS. However, much more work still needs to be done to determine whether this model is accurate(Magassaet al., 2010).

\subsection{Type-IVC Secretion System}

Type IV secretion system (T4SS) is one of versatile secretion systems essential for the virulence and even survival of some bacteria species, and they enable the secretion of protein and DNA substrates across the cell envelope(Cascales and Christie, 2003; Engel et al., 2011; Fronzes et al., 2009). T4SS was once believed to be present only in Gram-negative bacteria but has been found in Gram-positive organisms as well. Some research work support that in Gram-positive species of Streptococcus suis (S. suis), a GI-type T4SS-like system was identified in a new pathogenicity island (PAI) with a length of $89 \mathrm{~kb}$ (Chen et al., 2007), which was further proven to be a new subgroup of T4SS in this study. S. suis, a Gram-positive species of Streptococcus found in pigs, has recently caused a rash of human infections in China and gained public attention(Feng et al., 2010; Tang et al., 2006; Ye et al., 2006).

A new subgroup of T4SS (GI-type T4SS) was identified in Gram-positive strain S. suis(Chen et al., 2007; Li et al., 2011). Genetic organization represented that this GI-type T4SS in Gram-positive strain $S$. suis is clearly different with type-IVA, type-IVB and other T4SS in Gram-negative bacteria, thus it is classified as Type-IVC secretion system in this study. Different with other T4SS systems, only 4 proteins (VirB1, VirB4, VirB6, and VirD4) were identified in Type-IVC secretion systems, which mainly work in three fields: (1) transglycosylases (VirB1), working for degrading peptidoglycan outside the plasma membrane of bacteria, could reduce the resistance for the secretion of substrates; (2) ATPases (VirB4, and VirD4) play essential roles in supplying the energy for substrates translocation and apparatus assembly(Waksman and Fronzes, 2010). (3) a gene contributing to the assembly of the secretion channel across inner cell membrane(VirB6). These genes clustered together with the same direction in the chromosome. Those genes correspondent to channel subunit across outer membrane, such as VirB7/VirB9/VirB10 in type-IVA and DotD/DotC/DotH/DotG/DotF in type-IVB, were lost in type-IVC secretion system(Zhang et al., 2012).

\subsection{Function of Type-IVC Secretion System in Pathogenicity of Streptococcus}

The Type-IVC secretion system could enhance bacterial pathogenicity and mediate the injection of virulent proteins into host cells. The previous study showed that the two component system SalK/R within the 89-kb island controls the virulence of the highly pathogenic strain $S$. suis 2(Li et al., 2011). Recently, using NimbleGen tiling arrays, Zhu and colleagues found this 89-kb fragment in 9 other virulent $S$. suis 2 lineages, all of which were sampled from two recent large-scale outbreaks of human infection in China(Wu et al., 2011). The 89-kb GI which include Tn916 with tetracycline-resistance genes of the $S$. suis 2 strain was proved could laterally transfer to other $S$. suis 2 strains with the help of Type-IVC secretion system (Li et al., 2011). Knockout of the 2 key components (VirD4 and VirB4) of the S. suis 2 T4SS system eliminated the lethality of the highly virulent strain and impaired its ability to trigger host immune response in experimental infection of mice(Zhao et al., 2011). All of this evidence together suggests that Type-IVC secretion system contributes to the pathogenicity of $\boldsymbol{S}$. suis 2, particularly in the two outbreaks of $\boldsymbol{S}$. suis 2 infections in China(Zhang et al., 2012).

In S. pneumoniae TIGR4 (serotype 4), secY2 (transmembrane protein) and secA2 (ATPase) genes are foundwithin a 37-kb pathogenicity island encoding cell-surface pneumococcal serine-rich repeat protein (PsrP, 4776 aa residues). An additional 10 genes encode glycosylation enzymes, and five asp genes encode transport complex proteins(Obertet al., 2006; Tettelin et al., 2001). A similar locus is found in several but not all sequenced pneumococcal genomes. By analogy to genomic loci in Streptococcus gordonii and Streptococcus parasanguinis encoding serine-rich repeat (SRR) proteins GspB(Yen et al., 2013), Hsa and Fap1(Zhou et al., 2010), PsrP in S. pneumoniae is predicted to become post-translationally glycosylated concomitantly with secretion via the alternate SecY2A2/Asp1- 5 translocon(Shi et al., 2014). The streptococcal accessory Sec systems function to 
secrete SRR glycoproteins. However, the mechanism by which SRR proteins are directed to the accessory Sec system is not fully understood(Bandaraet al., 2017).

\section{Pathogenicity ISLANDS OF STReptococcus SPP.}

Pathogenicity islands (PAIs) term was coined by Hacker et al. to describe two large unstable regions on the chromosome of uropathogenicEscherichia coli (UPEC) (Hacker et al., 1990). PAIs encode various virulence. PAIs are considered to be a subclass of genomic islands that are acquired by horizontal gene transfer via transduction, conjugation and transformation, and provide 'quantum leaps' in microbial evolution(Gal-Mor and Finlay, 2006). It recently characterized in a wide range of bacterial pathogens have not only led to the identification of many virulence factors used by these species, but also changed our way of thinking about the evolution of bacterial pathogenicity(Gal-Mor and Finlay, 2006). Bacterial virulence and protein secretion systems determinants are predominantly encoded by or associated with mobile genetic elements such as phages, plasmids, insertion elements, or transposons, and a large number of such determinants are located within PAI(Schmidt and Hensel, 2004).

In contrast to $S$. aureus, PAI appear less relevant to the evolution of virulence in streptococci. The genome sequence of $S$. pyogenes revealed that a large number of virulence factors have been acquired by bacteriophage-mediated horizontal gene transfer but that PAI are absent from the genome(Ferretti et al., 2001). In contrast, a chromosomal region reminiscent of a PAI has been identified in $S$. pneumoniae. This locus was termed pneumococcal pathogenicity island 1 (PPI-1). PPI-1 is about 27 $\mathrm{kb}$ long, is absent in other streptococci and contains transposase and recombinase genes that may be related to the mobility of the locus. A virulence factor identified in PPI-1 is an iron uptake system encoded by pit $2 A B C D$. There is also the related pitl operon outside of the PAI, but full virulence of pneumococci in pulmonary and systemic animal models requires the function of both the Pit1 and Pit2 iron uptake systems(Brown et al., 2001).

Virulence factors of pathogenic bacteria (adhesins, toxins, invasins, protein secretion systems, iron uptake systems, and others) may be encoded by particular regions of the prokaryotic genome termed pathogenicity islands. The finding that the GC content of pathogenicity islands often differs from that of the rest of the genome, the presence of direct repeats at their ends, the association of pathogenicity islands with transfer RNA genes, the presence of integrase determinants and other mobility loci, and their genetic instability argue for the generation of pathogenicity islands by horizontal gene transfer, a process that is well known to contribute to microbial evolution(Hacker and Kaper, 2000).
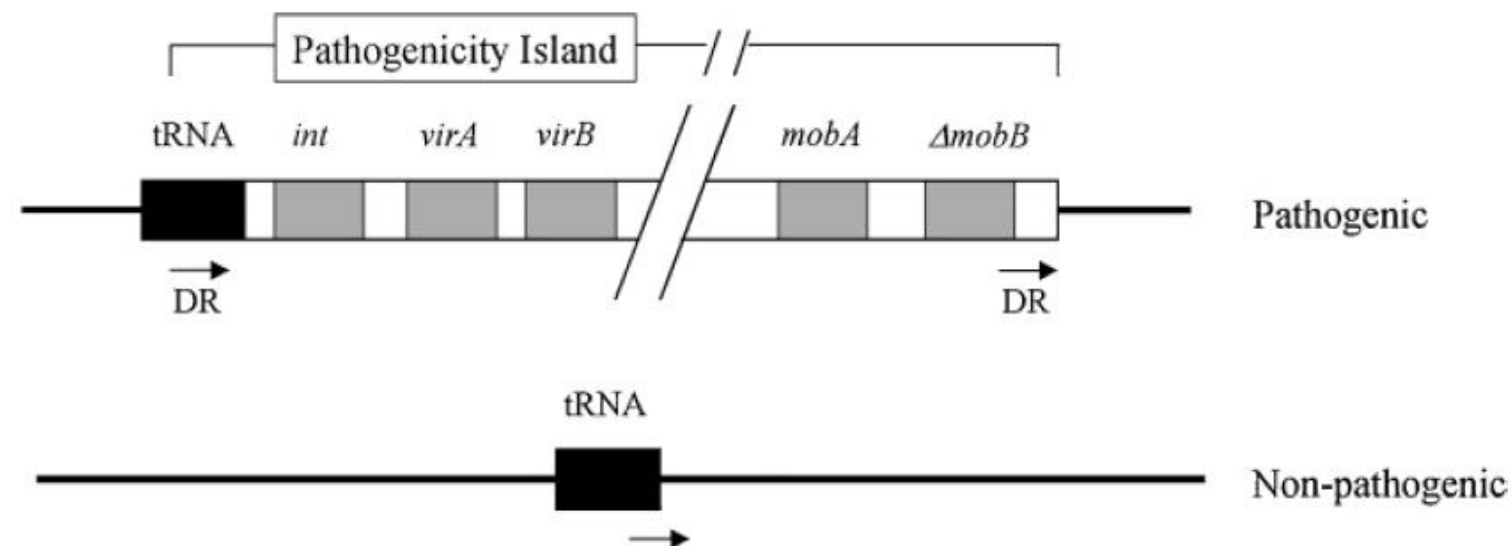

Figure 5. Model of a bacterial pathogenicity island.

Source: (Hacker et al., 1997; Hacker and Kaper, 2000).

The thin bold line represents regions of the core genome; pathogenicity island-specific sequences are indicated. The box represent genes. The arrows indicate the presence of direct repeats at the ends of the pathogenicity island. Abbreviations: DR, direct repeats; int, integrase gene; vir, virulenceassociated gene; mob, mobility gene; $1 \mathrm{mob}$, pseudo-mobility gene. mobgenes encode integrases, transposases, or other proteins involved in mobility of the prokaryotic genome. 


\subsection{Virulence-Associated Genes on Pathogenicity Islands}

Virulence factors encoded on PAIs represent the entire spectrum of bacterial virulence factors, from adhesins ,toxins, secretion systems, invasins, modulins, effectors, proteases, lipases, and enterotoxins, superantigens, iron uptake systems, immunoglobulin A proteases, capsule synthesis, host defense avoidance mechanisms(Hacker and Kaper, 2000). PAIs located in the genomes of various species and pathotypes encode adhesins, which mediate the capacity of microbes to attach to specific eukaryotic receptor molecules. PAIs of different UPEC isolates show the presence of additional genes with significant homologies to adhesin gene clusters such as the heat resistant hemagglutinin of enterotoxigenicE. coli, and a saliva-binding protein of Streptococcus sanguis(Hacker et al., 1999).

Some of the best characterized PAIs provide the host bacterium with the ability to invade epithelial cells and/or modulate host cell activities. Many bacterial pathogens harbor plasmids or bacteriophages which encode important toxins. Various enterotoxins of S. aureus and Streptococcus pyogenes with superantigen specificity are located on phages. Because so many bacterial toxin genes are located on plasmids and bacteriophages, it is not surprising that PAIs also often carry toxin-encoding genes. The prototypes of pore-forming PAI-encoded toxins are hemolysins of UPEC termed HlyA(Dobrindt and Hacker, 1999).

Superantigens have the capacity to bind to the T-cell receptor molecule and in turn activate these cells in a nonspecific manner. Many of these toxins are produced by $S$. pyogenes and $S$. aureus, in which the corresponding genes are often located on bacteriophages or plasmids. The toxic shock syndrome toxin (TSST)-1 toxin of $S$. aureus, however, is part of a 15-kb PAI (SaPI) which represents a defective bacteriophage. The SaPI can be mobilized by helper phages and transferred to other strains. Similar PAIs have been found in different $S$. aureus isolates, indicating that the occurrence of SaPIs is a general phenomenon in S. aureus(Lindsay et al., 1998).

Iron uptake systems are encoded by pathogenic as well as nonpathogenic members of the same species; however, they are more prevalent in pathogenic strains. This supports the hypothesis that iron uptake systems, as part of genomic islands in nonpathogenic strains, may contribute to the fitness of these organisms as well as their adaptability to particular environments, whereas in pathogenic bacteria these systems contribute to virulence. Accordingly, in nonpathogenic strains such DNA fragments are considered fitness islands while in pathogenic strains they represent PAIs. Survival and multiplication of microbes in certain ecological niches depend on the ability of these organisms to scavenge essential nutrients such as iron. For pathogenic bacteria the acquisition of iron is a prerequisite for the infectious process, but nonpathogenic organisms also need sufficient iron ions . At least two different strategies are used by bacteria to meet their iron needs: the expression of receptors for iron carriers (e.g. heme, hemoglobin, lactoferrin, and transferrin) and the synthesis and secretion of siderophores, which are low-molecular-weight, high affinity iron-binding compounds(Mietzner and Morse, 1994).

Immunoglobulin A Proteaseshave the capacity to cleave IgA1 molecules. Pathogenic organisms, such as Haemophilus influenzae, N. gonorrhoeae, Neisseria meningitidis, and Streptococcus pneumoniae, synthesize IgA proteases, while commensal strains of these species do not show this activity. The corresponding genes, however, have not formally been described as PAIs. A similar observation was made for the locus encoding the exopolysaccharide PAI of a biofilm positive subgroup of $S$. epidermidis. The corresponding genes, termed ica, are also located on a particular DNA segment of $>100 \mathrm{~kb}$ which is absent in biofilm negative strains(Henderson et al., 1998; Hersh et al., 1999).

\subsection{Collection of PAI loci of Streptococcus Species}

\section{Streptococcus equi}

\begin{tabular}{|l|l|l|l|l|l|c|}
\hline No & PAI & Host Strain & Function & $\begin{array}{c}\text { Insertion } \\
\text { Site }\end{array}$ & $\begin{array}{c}\text { GenBank Accession } \\
\text { (Size) }\end{array}$ & $\begin{array}{c}\text { No. of } \\
\text { Matched } \\
\text { Genomes* }\end{array}$ \\
\hline 1 & $\boldsymbol{\varphi}$ Seq2 & $\begin{array}{l}\text { Streptococcus } \\
\text { equi4047 }\end{array}$ & phosphlioase A2, SlaA & $\begin{array}{c}\text { Putative } \\
\text { C-terminal } \\
\text { sequence } \\
\text { of an } \\
\text { ATP- }\end{array}$ & $\begin{array}{l}\text { NC_012471_P1(44.1kb, } \\
\text { complete PAI in the } \\
\text { sequenced genome) }\end{array}$ & 18 \\
\hline
\end{tabular}


Review on Major Virulence Factors of Pathogenic Streptococcus Species

\begin{tabular}{|l|l|l|l|l|l|c|}
\hline \hline & & & $\begin{array}{l}\text { dependent } \\
\text { DNA } \\
\text { helicase }\end{array}$ & & \\
\hline 2 & $\boldsymbol{\varphi}$ Seq3 & $\begin{array}{l}\text { Streptococcus } \\
\text { equi4047 }\end{array}$ & SuperantigensSeeL\&SeeM & - & $\begin{array}{l}\text { NC_012471_P2(30.8kb, } \\
\text { complete PAI in the } \\
\text { sequenced genome) }\end{array}$ & 18 \\
\hline 3 & $\boldsymbol{\varphi}$ Seq4 & $\begin{array}{l}\text { Streptococcus } \\
\text { equi4047 }\end{array}$ & SuperantigensSeeH\&SeeI & tRNA-Lys & $\begin{array}{l}\text { NC_012471_P3(41.6kb, } \\
\text { complete PAI in the } \\
\text { sequenced genome) }\end{array}$ & 35 \\
\hline
\end{tabular}

Streptococcus gallolyticus

\begin{tabular}{|c|c|l|l|l|l|c|}
\hline No & PAI & Host Strain & Function & $\begin{array}{l}\text { Insertion } \\
\text { Site }\end{array}$ & $\begin{array}{c}\text { GenBank Accession } \\
\text { (Size) }\end{array}$ & $\begin{array}{c}\text { No. of } \\
\text { Matched } \\
\text { Genomes* }\end{array}$ \\
\hline 1 & Not named & $\begin{array}{l}\text { Streptococcus } \\
\text { gallolyticus ATCC } \\
\text { BAA-2069 }\end{array}$ & $\begin{array}{l}\text { Bacteriocin- } \\
\text { associated genes }\end{array}$ & tRNA-Leu & $\begin{array}{l}\text { NC_015215_P1(16.5kb, } \\
\text { complete PAI in the } \\
\text { sequenced genome) }\end{array}$ & 0 \\
\hline
\end{tabular}

\section{Streptococcus mitis}

\begin{tabular}{|c|l|l|l|l|l|c|}
\hline No & \multicolumn{1}{|c|}{ PAI } & Host Strain & Function & $\begin{array}{l}\text { Insertion } \\
\text { Site }\end{array}$ & $\begin{array}{c}\text { GenBank Accession } \\
\text { (Size) }\end{array}$ & $\begin{array}{c}\text { No. of } \\
\text { Matched } \\
\text { Genomes* }\end{array}$ \\
\hline 1 & $\begin{array}{l}\text { The } \\
\text { aminoglycoside } \\
\text { resistance gene } \\
\text { cluster }\end{array}$ & $\begin{array}{l}\text { Streptococcus } \\
\text { mitisB6 }\end{array}$ & $\begin{array}{l}\text { The } \\
\text { aminoglycoside } \\
\text { resistance gene } \\
\text { cluster }\end{array}$ & - & $\begin{array}{l}\text { NC_013853_P1(28.4kb, } \\
\text { complete PAI in the } \\
\text { sequenced genome) }\end{array}$ & 0 \\
\hline
\end{tabular}

\section{Streptococcus parasanguinis}

\begin{tabular}{|c|l|l|l|l|l|c|}
\hline No & \multicolumn{1}{|c|}{ PAI } & \multicolumn{1}{|c|}{ Host Strain } & Function & $\begin{array}{l}\text { Insertion } \\
\text { Site }\end{array}$ & $\begin{array}{c}\text { GenBank Accession } \\
\text { (Size) }\end{array}$ & $\begin{array}{c}\text { No. of } \\
\text { Matched } \\
\text { Genomes* }\end{array}$ \\
\hline 1 & FWisland_1 & $\begin{array}{l}\text { Streptococcus } \\
\text { parasanguinis FW213 }\end{array}$ & $\begin{array}{l}\text { Salivaricin B } \\
\text { and nisin } \\
\text { production }\end{array}$ & - & $\begin{array}{l}\text { NC_017905_P2(50.5kb, } \\
\text { complete PAI in the } \\
\text { sequenced genome) }\end{array}$ & 24 \\
\hline 2 & FWisland_2 & $\begin{array}{l}\text { Streptococcus } \\
\text { parasanguinis FW213 }\end{array}$ & $\begin{array}{l}\text { Bacteriocin } \\
\text { production }\end{array}$ & - & $\begin{array}{l}\text { NC_017905_P3(34.6kb, } \\
\text { complete PAI in the } \\
\text { sequenced genome) }\end{array}$ & 1 \\
\hline 3 & FWisland_3 & $\begin{array}{l}\text { Streptococcus } \\
\text { parasanguinis FW213 }\end{array}$ & $\begin{array}{l}\text { Fap1 } \\
\text { production } \\
\text { and fimbriae } \\
\text { maturation }\end{array}$ & $\begin{array}{l}\text { NC_017905_P4(23.8kb, } \\
\text { complete PAI in the } \\
\text { sequenced genome) }\end{array}$ & 0 \\
\hline 4 & FWisland_4 & $\begin{array}{l}\text { Streptococcus } \\
\text { parasanguinis FW213 }\end{array}$ & $\begin{array}{l}\text { EPS } \\
\text { production }\end{array}$ & - & $\begin{array}{l}\text { NC_017905_P5(29.4kb, } \\
\text { complete PAI in the } \\
\text { sequenced genome) }\end{array}$ & 7 \\
\hline 5 & FWisland_5 & $\begin{array}{l}\text { Streptococcus } \\
\text { parasanguinis FW213 }\end{array}$ & adc operon & - & $\begin{array}{l}\text { NC_017905_P1(11.3kb, } \\
\text { complete PAI in the } \\
\text { sequenced genome) }\end{array}$ & 0 \\
\hline
\end{tabular}

\section{Streptococcus pneumoniae}

\begin{tabular}{|c|c|l|l|l|l|c|}
\hline No & PAI & \multicolumn{1}{|c|}{ Host Strain } & Function & Insertion Site & $\begin{array}{c}\text { GenBank Accession } \\
\text { (Size) }\end{array}$ & $\begin{array}{c}\text { No. of } \\
\text { Matched } \\
\text { Genomes* }\end{array}$ \\
\hline 1 & PPI-1 & $\begin{array}{l}\text { Streptococcus } \\
\text { pneumoniae ATCC }\end{array}$ & $\begin{array}{l}\text { pezAT epsilon } \\
\text { toxin-zeta }\end{array}$ & - & $\begin{array}{l}\text { NC_011900_P1(28.6kb, } \\
\text { complete PAI in the }\end{array}$ & 23 \\
\hline
\end{tabular}


Review on Major Virulence Factors of Pathogenic Streptococcus Species

\begin{tabular}{|l|l|l|l|l|l|c|}
\hline \hline & & 700669 & $\begin{array}{l}\text { antitoxin } \\
\text { system }\end{array}$ & sequenced genome) & \\
\hline 2 & PPI-1 & $\begin{array}{l}\text { Streptococcus } \\
\text { pneumoniae TIGR4 }\end{array}$ & $\begin{array}{l}\text { Iron uptake } \\
\text { (piaABCD) }\end{array}$ & SP1029/SP1067 & $\begin{array}{l}\text { NC_003028_P1(28.3kb, } \\
\text { complete PAI in the } \\
\text { sequenced genome) }\end{array}$ & 23 \\
\hline & & & & & \\
\hline
\end{tabular}

\section{Streptococcus pyogenes}

\begin{tabular}{|c|c|c|c|c|c|c|}
\hline No & PAI & Host Strain & Function & $\begin{array}{l}\text { Insertion } \\
\text { Site }\end{array}$ & $\begin{array}{c}\text { GenBank Accession } \\
\text { (Size) }\end{array}$ & $\begin{array}{c}\text { No. of } \\
\text { Matched } \\
\text { Genomes* }\end{array}$ \\
\hline 1 & $\begin{array}{l}\text { Not } \\
\text { named }\end{array}$ & $\begin{array}{l}\text { Streptococcus } \\
\text { pyogenes MGAS5005 }\end{array}$ & $\begin{array}{l}\text { 36-kb } \\
\text { chromosomal } \\
\text { region encoding } \\
\text { the extracellular } \\
\text { toxins, NAD+- } \\
\text { glycohydrolase } \\
\text { (NADase) and } \\
\text { streptolysin O } \\
\text { (SLO) }\end{array}$ & purA/nadC & $\begin{array}{l}\text { NC_007297_P1 }(36.0 \mathrm{~kb} \text {, } \\
\text { complete PAI in the } \\
\text { sequenced genome })\end{array}$ & 5 \\
\hline 2 & RD2 & $\begin{array}{l}\text { Streptococcus } \\
\text { pyogenes MGAS6180 }\end{array}$ & $\begin{array}{l}\text { 37.4-kb DNA } \\
\text { segment that } \\
\text { encodes } 7 \\
\text { inferred } \\
\text { extracellular } \\
\text { proteins, } \\
\text { including } 4 \text { with } \\
\text { an LPXTG } \\
\text { carboxy terminal } \\
\text { motif } \\
\text { characteristic of } \\
\text { cell-surface } \\
\text { anchored } \\
\text { proteins }\end{array}$ & - & $\begin{array}{l}\text { NC_007296_P1 }(37.4 \mathrm{~kb} \text {, } \\
\text { complete PAI in the } \\
\text { sequenced genome })\end{array}$ & 2 \\
\hline
\end{tabular}

\section{Streptococcus suis}

\begin{tabular}{|c|l|l|l|l|l|c|}
\hline No & \multicolumn{1}{|c|}{ PAI } & Host Strain & \multicolumn{1}{|c|}{ Function } & $\begin{array}{l}\text { Insertion } \\
\text { Site }\end{array}$ & \multicolumn{1}{|c|}{$\begin{array}{c}\text { GenBank Accession } \\
\text { (Size) }\end{array}$} & $\begin{array}{c}\text { No. of } \\
\text { Matched } \\
\text { Genomes* }\end{array}$ \\
\hline 1 & $\mathbf{8 9 K}$ & $\begin{array}{l}\text { Streptococcus } \\
\text { suis05ZYH33 }\end{array}$ & $\begin{array}{l}\text { Streptococcal toxic } \\
\text { shock syndrome } \\
\text { (STSS) }\end{array}$ & - & $\begin{array}{l}\text { NC_009442_P1(88.6kb, } \\
\text { complete PAI in the } \\
\text { sequenced genome) }\end{array}$ & 16 \\
\hline 2 & $\mathbf{8 9 K}$ & $\begin{array}{l}\text { Streptococcus } \\
\text { suis98HAH33 }\end{array}$ & $\begin{array}{l}\text { Streptococcal toxic } \\
\text { shock syndrome } \\
\text { (STSS) }\end{array}$ & - & $\begin{array}{l}\text { NC_009443_P1(88.6kb, } \\
\text { complete PAI in the } \\
\text { sequenced genome) }\end{array}$ & 16 \\
\hline
\end{tabular}

\section{Streptomyces turgidiscabies}

\begin{tabular}{|c|c|c|c|c|c|c|}
\hline No & PAI & Host Strain & Function & $\begin{array}{l}\text { Insertion } \\
\text { Site }\end{array}$ & $\begin{array}{c}\text { GenBank } \\
\text { Accession } \\
\text { (Size) }\end{array}$ & $\begin{array}{c}\text { No. of } \\
\text { Matched } \\
\text { Genomes* }\end{array}$ \\
\hline 1 & Not named & $\begin{array}{l}\text { Streptomyces } \\
\text { turgidiscabies Car8 }\end{array}$ & $\begin{array}{l}\text { Thaxtomin } \\
\text { biosynthetic } \\
\text { pathway, nec1, a } \\
\text { putative tomatinase } \\
\text { gene }\end{array}$ & $\begin{array}{c}\text { Not } \\
\text { published }\end{array}$ & $\begin{array}{l}\text { AY707079 } \\
(4.6 \mathrm{~kb}) \\
\text { AY707080 } \\
(11.0 \mathrm{~kb}) \\
\text { AY707081 } \\
(33.2 \mathrm{~kb})\end{array}$ & 1 \\
\hline
\end{tabular}




\begin{tabular}{|l|l|l|l|l|}
\hline \hline & & & $\begin{array}{l}\text { AY707082 } \\
(0.9 \mathrm{~kb}) \\
\text { AY707083 } \\
(0.1 \mathrm{~kb})\end{array}$ \\
\hline
\end{tabular}

Table. 2. PAI loci of Streptococcus Species

Source: (http://www.paidb.re.kr/browse_pais.php?m=p\#Streptococcus pneumoniae)

\section{CONCLUSION}

Streptococci is the general term for a diverse collection of Gram-positive cocci that typically grow as chains or pairs. The genus Streptococcus includes important pathogens and commensals of mucosal membranes of the upper respiratory tract and, for some species, the intestines. The genus Streptococcus includes nearly 40 species. With few exceptions, the individual species are exclusively associated, either as pathogens or commensals, with man or a particular animal.Virulence factors of streptococci species include such as $\mathrm{M}$ protein,lipoteichoic acid for attachment, a hyaluronic acid capsule that inhibits phagocytosis;pyrogenic (erythrogenic) toxin, which causes the rash of scarlet fever, capsule, pili, streptokinase, DNase B, and streptolysins.Secreted proteins can play many roles in promoting bacterial virulence, from enhancing attachment to eukaryotic cells, to scavenging resources in an environmental niche, to directly intoxicating target cells and disrupting their functions. Virulence factors encoded on pathogenic islands represent the entire spectrum of bacterial virulence factors, from adhesins ,toxins, secretion systems, invasins, modulins, effectors, proteases, lipases, and enterotoxins, superantigens, iron uptake systems, immunoglobulin A proteases, capsule synthesis, host defense avoidance mechanisms.

\section{REFERENCES}

Anderson, E.T., Wetherell, M.G., Winter, L.A., Olmsted, S.B., Cleary, P.P., Matsuka, Y. V, 2002. Processing, stability, and kinetic parameters of C5a peptidase from Streptococcus pyogenes. FEBS J. 269, 4839-4851.

Anderson, R., Feldman, C., 2011. Key virulence factors of Streptococcus pneumoniae and non-typeable Haemophilus infuenzae: roles in host defence and immunisation. South. African J. Epidemiol. Infect. 26, $6-12$.

Baker, J.R., Dong, S., Pritchard, D.G., 2002. The hyaluronan lyase of Streptococcus pyogenes bacteriophage H4489A. Biochem. J. 365, 317.

Bandara, M., Skehel, J.M., Kadioglu, A., Collinson, I., Nobbs, A.H., Blocker, A.J., Jenkinson, H.F., 2017. The accessory Sec system (SecY2A2) in Streptococcus pneumoniae is involved in export of pneumolysin toxin, adhesion and biofilm formation. Microbes Infect. 19, 402-412.

Bensing, B.A., Seepersaud, R., Yen, Y.T., Sullam, P.M., 2014. Selective transport by SecA2: an expanding family of customized motor proteins. Biochim. Biophys. Acta (BBA)-Molecular Cell Res. 1843, 16741686.

Beulin, D.S.J., Yamaguchi, M., Kawabata, S., Ponnuraj, K., 2014. Crystal structure of PfbA, a surface adhesin of Streptococcus pneumoniae, provides hints into its interaction with fibronectin. Int. J. Biol. Macromol. 64, 168-173.

Bhakdi, S., Tranum-Jensen, J., 1985. Membrane damage by channel-forming proteins: staphylococcal alphatoxin, streptolysin-O and the C5b-9 complement complex., in: Biochemical Society Symposium. pp. 221233.

Bhakdi, S., Tranum-Jensen, J., Sziegoleit, A., 1985. Mechanism of membrane damage by streptolysin-O. Infect. Immun. 47, 52-60.

Binsker, U., Kohler, T.P., Krauel, K., Kohler, S., Schwertz, H., Hammerschmidt, S., 2015. Pneumococcal adhesins PavB and PspC are important for the interplay with human thrombospondin-1. J. Biol. Chem. 290, 14542-14555.

Bisno, A.L., Brito, M.O., Collins, C.M., 2003. Molecular basis of group A streptococcal virulence. Lancet Infect. Dis. 3, 191-200.

Bohnsack, J.F., Mollison, K.W., Buko, A.M., Ashworth, J.C., Hill, H.R., 1991. Group B streptococci inactivate complement component C5a by enzymic cleavage at the C-terminus. Biochem. J. 273, 635.

Bolduc, G.R., Baron, M.J., Gravekamp, C., Lachenauer, C.S., Madoff, L.C., 2002. The alpha C protein mediates internalization of group B Streptococcus within human cervical epithelial cells. Cell. Microbiol. 4, 751758.

Brittan, J.L., Nobbs, A.H., 2015. Group B Streptococcus pili mediate adherence to salivary glycoproteins. 
Microbes Infect. 17, 360-368.

Brown, J.S., Gilliland, S.M., Holden, D.W., 2001. A Streptococcus pneumoniae pathogenicity island encoding an $\mathrm{ABC}$ transporter involved in iron uptake and virulence. Mol. Microbiol. 40, 572-585.

Byarugaba, D.K., 2004. Antimicrobial resistance in developing countries and responsible risk factors. Int. J. Antimicrob. Agents 24, 105-110.

Carlsson, F., Berggård, K., Stålhammar-Carlemalm, M., Lindahl, G., 2003. Evasion of phagocytosis through cooperation between two ligand-binding regions in Streptococcus pyogenes M protein. J. Exp. Med. 198, 1057-1068.

Cascales, E., Christie, P.J., 2003. The versatile bacterial type IV secretion systems. Nat. Rev. Microbiol. 1, 137.

Chamcha, V., Jones, A., Quigley, B.R., Scott, J.R., Amara, R.R., 2015. Oral Immunization with a Recombinant Lactococcus lactis-Expressing HIV-1 Antigen on Group A Streptococcus Pilus Induces Strong Mucosal Immunity in the Gut. J. Immunol. 195, 5025-5034.

Chen, C., Tang, J., Dong, W., Wang, C., Feng, Y., Wang, J., Zheng, F., Pan, X., Liu, D., Li, M., 2007. A glimpse of streptococcal toxic shock syndrome from comparative genomics of S. suis 2 Chinese isolates. PLoS One 2, e315.

Chen, L., Yang, J., Yu, J., Yao, Z., Sun, L., Shen, Y., Jin, Q., 2005. VFDB: a reference database for bacterial virulence factors. Nucleic Acids Res. 33, D325-D328.

Chen, Q., Wu, H., Kumar, R., Peng, Z., Fives-Taylor, P.M., 2006. SecA2 is distinct from SecA in immunogenic specificity, subcellular distribution and requirement for membrane anchoring in Streptococcus parasanguis. FEMS Microbiol. Lett. 264, 174-181.

Cleary, P.P., Peterson, J., Chen, C., Nelson, C., 1991. Virulent human strains of group G streptococci express a C5a peptidase enzyme similar to that produced by group A streptococci. Infect. Immun. 59, 2305-2310.

Cockeran, R., Anderson, R., Feldman, C., 2002a. The role of pneumolysin in the pathogenesis of Streptococcus pneumoniae infection. Curr. Opin. Infect. Dis. 15, 235-239.

Cockeran, R., Durandt, C., Feldman, C., Mitchell, T.J., Anderson, R., 2002b. Pneumolysin activates the synthesis and release of interleukin-8 by human neutrophils in vitro. J. Infect. Dis. 186, 562-565.

Cunningham, M.W., 2000. Pathogenesis of group A streptococcal infections. Clin. Microbiol. Rev. 13, 470511.

De Las Rivas, B., García, J.L., López, R., García, P., 2002. Purification and polar localization of pneumococcal LytB, a putative endo- $\beta$-N-acetylglucosaminidase: the chain-dispersing murein hydrolase. J. Bacteriol. 184, 4988-5000.

Devi, A.S., Ponnuraj, K., 2010. Cloning, expression, purification and ligand binding studies of novel fibrinogenbinding protein FbsB of Streptococcus agalactiae. Protein Expr. Purif. 74, 148-155.

Dobrindt, U., Hacker, J., 1999. Plasmids, phages and pathogenicity islands: lessons on the evolution of bacterial toxins. Compr. Sourceb. Bact. protein toxins, 2nd ed. Acad. Press. London, United Kingdom 3-23.

Doran, K.S., Chang, J.C.W., Benoit, V.M., Eckmann, L., Nizet, V., 2002. Group B streptococcal $\beta$ hemolysin/cytolysin promotes invasion of human lung epithelial cells and the release of interleukin-8. J. Infect. Dis. 185, 196-203.

Engel, P., Salzburger, W., Liesch, M., Chang, C.-C., Maruyama, S., Lanz, C., Calteau, A., Lajus, A., Médigue, C., Schuster, S.C., 2011. Parallel evolution of a type IV secretion system in radiating lineages of the hostrestricted bacterial pathogen Bartonella. PLoS Genet. 7, e1001296.

Feldman, C., Anderson, R., Cockeran, R., Mitchell, T., Cole, P., Wilson, R., 2002. The effects of pneumolysin and hydrogen peroxide, alone and in combination, on human ciliated epithelium in vitro. Respir. Med. 96, $580-585$.

Feng, Y., Zhang, H., Ma, Y., Gao, G.F., 2010. Uncovering newly emerging variants of Streptococcus suis, an important zoonotic agent. Trends Microbiol. 18, 124-131.

Ferretti, J.J., McShan, W.M., Ajdic, D., Savic, D.J., Savic, G., Lyon, K., Primeaux, C., Sezate, S., Suvorov, A.N., Kenton, S., 2001. Complete genome sequence of an M1 strain of Streptococcus pyogenes. Proc. Natl. Acad. Sci. 98, 4658-4663.

Fischetti, V.A., 1989. Streptococcal M protein: molecular design and biological behavior. Clin. Microbiol. Rev. 2, 285-314.

Frick, I.-M., Åkesson, P., Rasmussen, M., Schmidtchen, A., Björck, L., 2003. SIC, a Secreted Protein of Streptococcus pyogenesThat Inactivates Antibacterial Peptides. J. Biol. Chem. 278, 16561-16566.

Fronzes, R., Christie, P.J., Waksman, G., 2009. The structural biology of type IV secretion systems. Nat. Rev. Microbiol. 7, 703.

Gal-Mor, O., Finlay, B.B., 2006. Pathogenicity islands: a molecular toolbox for bacterial virulence. Cell. Microbiol. 8, 1707-1719. 
Ghosh, J., Anderson, P.J., Chandrasekaran, S., Caparon, M.G., 2010. Characterization of Streptococcus pyogenes $\beta$-NAD+ Glycohydrolase RE-EVALUATION OF ENZYMATIC PROPERTIES ASSOCIATED WITH PATHOGENESIS. J. Biol. Chem. 285, 5683-5694.

Ghosh, J., Caparon, M.G., 2006. Specificity of Streptococcus pyogenes NAD+ glycohydrolase in cytolysin-mediated translocation. Mol. Microbiol. 62, 1203-1214.

Green, E.R., Mecsas, J., 2016. Bacterial secretion systems-an overview. Microbiol. Spectr. 4.

Greenwood, D., Slack, R.C.B., Barer, M.R., Irving, W.L., 2012. Medical Microbiology E-Book: A Guide to Microbial Infections: Pathogenesis, Immunity, Laboratory Diagnosis and Control. With STUDENT CONSULT Online Access. Elsevier Health Sciences.

Gutekunst, H., Eikmanns, B.J., Reinscheid, D.J., 2004. The novel fibrinogen-binding protein FbsB promotes Streptococcus agalactiae invasion into epithelial cells. Infect. Immun. 72, 3495-3504.

Hacker, J., Bender, L., Ott, M., Wingender, J., Lund, B., Marre, R., Goebel, W., 1990. Deletions of chromosomal regions coding for fimbriae and hemolysins occur in vitro and in vivo in various extra intestinal Escherichia coli isolates. Microb. Pathog. 8, 213-225.

Hacker, J., Blum-Oehler, G., Janke, B., Nagy, G., Goebel, W., 1999. Pathogenicity islands of extraintestinal Escherichia coli, in: Pathogenicity Islands and Other Mobile Virulence Elements. American Society of Microbiology, pp. 59-76.

Hacker, J., Blum-Oehler, G., Mühldorfer, I., Tschäpe, H., 1997. Pathogenicity islands of virulent bacteria: structure, function and impact on microbial evolution. Mol. Microbiol. 23, 1089-1097.

Hacker, J., Kaper, J.B., 2000. Pathogenicity islands and the evolution of microbes. Annu. Rev. Microbiol. 54, 641-679.

Hall-Stoodley, L., Stoodley, P., 2009. Evolving concepts in biofilm infections. Cell. Microbiol. 11, $1034-1043$.

Henderson, I.R., Navarro-Garcia, F., Nataro, J.P., 1998. The great escape: structure and function of the autotransporter proteins. Trends Microbiol. 6, 370-378.

Hendrickx, A.P.A., Budzik, J.M., Oh, S.-Y., Schneewind, O., 2011. Architects at the bacterial surface-sortases and the assembly of pili with isopeptide bonds. Nat. Rev. Microbiol. 9, 166.

Hersh, D., Monack, D.M., Smith, M.R., Ghori, N., Falkow, S., Zychlinsky, A., 1999. The Salmonella invasin SipB induces macrophage apoptosis by binding to caspase-1. Proc. Natl. Acad. Sci. 96, 2396-2401.

Herwald, H., Cramer, H., Mörgelin, M., Russell, W., Sollenberg, U., Norrby-Teglund, A., Flodgaard, H., Lindbom, L., Björck, L., 2004. M protein, a classical bacterial virulence determinant, forms complexes with fibrinogen that induce vascular leakage. Cell 116, 367-379.

Hidalgo-Grass, C., Mishalian, I., Dan-Goor, M., Belotserkovsky, I., Eran, Y., Nizet, V., Peled, A., Hanski, E., 2006. A streptococcal protease that degrades CXC chemokines and impairs bacterial clearance from infected tissues. EMBO J. 25, 4628-4637.

Hoe, N.P., Ireland, R.M., DeLeo, F.R., Gowen, B.B., Dorward, D.W., Voyich, J.M., Liu, M., Burns, E.H., Culnan, D.M., Bretscher, A., 2002. Insight into the molecular basis of pathogen abundance: group A Streptococcus inhibitor of complement inhibits bacterial adherence and internalization into human cells. Proc. Natl. Acad. Sci. 99, 7646-7651.

Hogan, D., Kolter, R., 2002. Why are bacteria refractory to antimicrobials? Curr. Opin. Microbiol. 5, 472-477.

Jedrzejas, M.J., 2001. Pneumococcal virulence factors: structure and function. Microbiol. Mol. Biol. Rev. 65 , 187-207.

Ji, Y., McLandsborough, L., Kondagunta, A., Cleary, P.P., 1996. C5a peptidase alters clearance and trafficking of group A streptococci by infected mice. Infect. Immun. 64, 503-510.

Johnson, D.I., 2018a. Bacterial Pathogens and Their Virulence Factors. Springer.

Johnson, D.I., 2018b. Streptococcus spp., in: Bacterial Pathogens and Their Virulence Factors. Springer, pp. $151-174$.

Kadioglu, A., Brewin, H., Härtel, T., Brittan, J.L., Klein, M., Hammerschmidt, S., Jenkinson, H.F., 2010. Pneumococcal protein PavA is important for nasopharyngeal carriage and development of sepsis. Mol. Oral Microbiol. 25, 50-60.

Kadioglu, A., Taylor, S., Iannelli, F., Pozzi, G., Mitchell, T.J., Andrew, P.W., 2002. Upper and lower respiratory tract infection by Streptococcus pneumoniae is affected by pneumolysin deficiency and differences in capsule type. Infect. Immun. 70, 2886-2890.

Kadioglu, A., Weiser, J.N., Paton, J.C., Andrew, P.W., 2008. The role of Streptococcus pneumoniae virulence factors in host respiratory colonization and disease. Nat. Rev. Microbiol. 6, 288.

Keen, E.C., 2012. Paradigms of pathogenesis: targeting the mobile genetic elements of disease. Front. Cell. Infect. Microbiol. 2, 161. 
Kilian, M., 2002. Streptococcus and enterococcus. Med. Microbiol. 17, 178-193.

Kilian, M., 2000. Streptococcus and enterococcus.

Kreikemeyer, B., Oehmcke, S., Nakata, M., Hoffrogge, R., Podbielski, A., 2004. Streptococcus pyogenes fibronectin-binding protein F2 expression profile, binding characteristics, and impact on eukaryotic cell interactions. J. Biol. Chem. 279, 15850-15859.

Kreil, G., 1995. Hyaluronidases - a group of neglected enzymes. Protein Sci. 4, 1666-1669.

Lähteenmäki, K., Kuusela, P., Korhonen, T.K., 2001. Bacterial plasminogen activators and receptors. FEMS Microbiol. Rev. 25, 531-552.

Lancefield, R.C., 1962. Current knowledge of type-specific M antigens of group A streptococci. J. Immunol. 89, $307-313$.

Lancefield, R.C., 1940. Type-specific antigens, M and T, of matt and glossy variants of group A hemolytic streptococci. J. Exp. Med. 71, 521-537.

Lang, S., Palmer, M., 2003. Characterization of Streptococcus agalactiae CAMP factor as a pore-forming toxin. J. Biol. Chem. 278, 38167-38173.

Lauer, P., Rinaudo, C.D., Soriani, M., Margarit, I., Maione, D., Rosini, R., Taddei, A.R., Mora, M., Rappuoli, R., Grandi, G., 2005. Genome analysis reveals pili in Group B Streptococcus. Science (80-. ). 309, 105.

Lei, B., Liu, M., Meyers, E.G., Manning, H.M., Nagiec, M.J., Musser, J.M., 2003. Histidine and aspartic acid residues important for immunoglobulin $G$ endopeptidase activity of the group A Streptococcus opsonophagocytosis-inhibiting Mac protein. Infect. Immun. 71, 2881-2884.

Li, M., Shen, X., Yan, J., Han, H., Zheng, B., Liu, D., Cheng, H., Zhao, Y., Rao, X., Wang, C., 2011. GI-type T4SS-mediated horizontal transfer of the $89 \mathrm{~K}$ pathogenicity island in epidemic Streptococcus suis serotype 2. Mol. Microbiol. 79, 1670-1683.

Lin, B., Hollingshead, S.K., Coligan, J.E., Egan, M.L., Baker, J.R., Pritchard, D.G., 1994. Cloning and expression of the gene for group B streptococcal hyaluronate lyase. J. Biol. Chem. 269, 30113-30116.

Lindsay, J.A., Ruzin, A., Ross, H.F., Kurepina, N., Novick, R.P., 1998. The gene for toxic shock toxin is carried by a family of mobile pathogenicity islands in Staphylococcus aureus. Mol. Microbiol. 29, 527-543.

Llewelyn, M., Cohen, J., 2002. Superantigens: microbial agents that corrupt immunity. Lancet Infect. Dis. 2 , $156-162$.

Madden, J.C., Ruiz, N., Caparon, M., 2001. Cytolysin-mediated translocation (CMT): a functional equivalent of type III secretion in gram-positive bacteria. Cell 104, 143-152.

Magassa, N., Chandrasekaran, S., Caparon, M.G., 2010. Streptococcus pyogenes cytolysin-mediated translocation does not require pore formation by streptolysin O. EMBO Rep. 11, 400-405.

Maisey, H.C., Hensler, M., Nizet, V., Doran, K.S., 2007. Group B streptococcal pilus proteins contribute to adherence to and invasion of brain microvascular endothelial cells. J. Bacteriol. 189, 1464-1467.

Malley, R., Henneke, P., Morse, S.C., Cieslewicz, M.J., Lipsitch, M., Thompson, C.M., Kurt-Jones, E., Paton, J.C., Wessels, M.R., Golenbock, D.T., 2003. Recognition of pneumolysin by Toll-like receptor 4 confers resistance to pneumococcal infection. Proc. Natl. Acad. Sci. 100, 1966-1971.

Mazmanian, S.K., Liu, G., Ton-That, H., Schneewind, O., 1999. Staphylococcus aureus sortase, an enzyme that anchors surface proteins to the cell wall. Science (80-. ). 285, 760-763.

McAllister, L.J., Tseng, H., Ogunniyi, A.D., Jennings, M.P., McEwan, A.G., Paton, J.C., 2004. Molecular analysis of the psa permease complex of Streptococcus pneumoniae. Mol. Microbiol. 53, 889-901.

Merz, A.J., So, M., 2000. Interactions of pathogenic neisseriae with epithelial cell membranes. Annu. Rev. Cell Dev. Biol. 16, 423-457.

Mietzner, T.A., Morse, S.A., 1994. The role of iron-binding proteins in the survival of pathogenic bacteria. Annu. Rev. Nutr. 14, 471-493.

Mistou, M.-Y., Dramsi, S., Brega, S., Poyart, C., Trieu-Cuot, P., 2009. Molecular dissection of the secA2 locus of group B Streptococcus reveals that glycosylation of the Srr1 LPXTG protein is required for full virulence. J. Bacteriol. 191, 4195-4206.

Mitchell, T.J., 2003. The pathogenesis of streptococcal infections: from tooth decay to meningitis. Nat. Rev. Microbiol. 1, 219.

Morens, D.M., Folkers, G.K., Fauci, A.S., 2004. The challenge of emerging and re-emerging infectious diseases. Nature 430, 242.

Mozola, C.C., Caparon, M.G., 2015. Dual modes of membrane binding direct pore formation by Streptolysin O. Mol. Microbiol. 97, 1036-1050.

Mylvaganam, H., Bjorvatn, B., Hofstad, T., Osland, A., 2000. Molecular characterization and allelic distribution of the phage-mediated hyaluronidase genes hylP andhylP2 among Group A streptococci from western 
Norway. Microb. Pathog. 29, 145-153.

Nizet, V., 2002. Streptococcal $\beta$-hemolysins: genetics and role in disease pathogenesis. Trends Microbiol. 10, $575-580$.

Obert, C., Sublett, J., Kaushal, D., Hinojosa, E., Barton, T., Tuomanen, E.I., Orihuela, C.J., 2006. Identification of a candidate Streptococcus pneumoniae core genome and regions of diversity correlated with invasive pneumococcal disease. Infect. Immun. 74, 4766-4777.

Oggioni, M.R., Memmi, G., Maggi, T., Chiavolini, D., Iannelli, F., Pozzi, G., 2003. Pneumococcal zinc metalloproteinase $\mathrm{ZmpC}$ cleaves human matrix metalloproteinase 9 and is a virulence factor in experimental pneumonia. Mol. Microbiol. 49, 795-805.

Orihuela, C.J., Gao, G., Mcgee, M., Yu, J., Francis, K.P., Tuomanen, E., 2003. Organ-specific models of Streptococcus pneumoniae disease. Scand. J. Infect. Dis. 35, 647-652.

Orihuela, C.J., Mahdavi, J., Thornton, J., Mann, B., Wooldridge, K.G., Abouseada, N., Oldfield, N.J., Self, T., Ala'Aldeen, D.A.A., Tuomanen, E.I., 2009. Laminin receptor initiates bacterial contact with the blood brain barrier in experimental meningitis models. J. Clin. Invest. 119, 1638-1646.

Orrskog, S., Rounioja, S., Spadafina, T., Gallotta, M., Norman, M., Hentrich, K., Fälker, S., Ygberg-Eriksson, S., Hasenberg, M., Johansson, B., 2013. Pilus adhesin RrgA interacts with complement receptor 3, thereby affecting macrophage function and systemic pneumococcal disease. MBio 4, e00535-12.

Pietrocola, G., Visai, L., Valtulina, V., Vignati, E., Rindi, S., Arciola, C.R., Piazza, R., Speziale, P., 2006. Multiple interactions of FbsA, a surface protein from Streptococcus agalactiae, with fibrinogen: affinity, stoichiometry, and structural characterization. Biochemistry 45, 12840-12852.

Pinkney, M., Kapur, V., Smith, J., Weller, U., Palmer, M., Glanville, M., Messner, M., Musser, J.M., Bhakdi, S., Kehoe, M.A., 1995. Different forms of streptolysin O produced by Streptococcus pyogenes and by Escherichia coli expressing recombinant toxin: cleavage by streptococcal cysteine protease. Infect. Immun. 63, 2776-2779.

Pointon, J.A., Smith, W.D., Saalbach, G., Crow, A., Kehoe, M.A., Banfield, M.J., 2010. A highly unusual thioester bond in a pilus adhesin is required for efficient host cell interaction. J. Biol. Chem. 285, 3385833866.

Pracht, D., Elm, C., Gerber, J., Bergmann, S., Rohde, M., Seiler, M., Kim, K.S., Jenkinson, H.F., Nau, R., Hammerschmidt, S., 2005. PavA of Streptococcus pneumoniae modulates adherence, invasion, and meningeal inflammation. Infect. Immun. 73, 2680-2689.

Preston, J.A., Dockrell, D.H., 2008. Virulence factors in pneumococcal respiratory pathogenesis.

Proft, T., Webb, P.D., Handley, V., Fraser, J.D., 2003. Two novel superantigens found in both group A and group C Streptococcus. Infect. Immun. 71, 1361-1369.

Ragunathan, P., Sridaran, D., Weigel, A., Shabayek, S., Spellerberg, B., Ponnuraj, K., 2013. Metal binding is critical for the folding and function of laminin binding protein, Lmb of Streptococcus agalactiae. PLoS One 8, e67517.

Ren, B., Szalai, A.J., Hollingshead, S.K., Briles, D.E., 2004. Effects of PspA and antibodies to PspA on activation and deposition of complement on the pneumococcal surface. Infect. Immun. 72, 114-122.

Rigden, D.J., Jedrzejas, M.J., 2003. Structures of Streptococcus pneumoniae Hyaluronate Lyase in Complex with Chondroitin and Chondroitin Sulfate Disaccharides INSIGHTS INTO SPECIFICITY AND MECHANISM OF ACTION. J. Biol. Chem. 278, 50596-50606.

Ring, A., Weiser, J.N., Tuomanen, E.I., 1998. Pneumococcal trafficking across the blood-brain barrier. Molecular analysis of a novel bidirectional pathway. J. Clin. Invest. 102, 347-360.

Rosenau, A., Martins, K., Amor, S., Gannier, F., Lanotte, P., van der Mee-Marquet, N., Mereghetti, L., Quentin, R., 2007. Evaluation of the ability of Streptococcus agalactiae strains isolated from genital and neonatal specimens to bind to human fibrinogen and correlation with characteristics of the fbsA and fbsB genes. Infect. Immun. 75, 1310-1317.

Rosini, R., Rinaudo, C.D., Soriani, M., Lauer, P., Mora, M., Maione, D., Taddei, A., Santi, I., Ghezzo, C., Brettoni, C., 2006. Identification of novel genomic islands coding for antigenic pilus-like structures in Streptococcus agalactiae. Mol. Microbiol. 61, 126-141.

Schmidt, H., Hensel, M., 2004. Pathogenicity islands in bacterial pathogenesis. Clin. Microbiol. Rev. 17, 14-56.

Seepersaud, R., Bensing, B.A., Yen, Y.T., Sullam, P.M., 2010. Asp3 mediates multiple protein-protein interactions within the accessory Sec system of Streptococcus gordonii. Mol. Microbiol. 78, 490-505.

Shaik, M.M., Lombardi, C., Trindade, D.M., Fenel, D., Schoehn, G., Di Guilmi, A.M., Dessen, A., 2015. A structural snapshot of type II pilus formation in Streptococcus pneumoniae. J. Biol. Chem. 290, 2258122592.

Sharma, P., Lata, H., Arya, D.K., Kashyap, A.K., Kumar, H., Dua, M., Ali, A., Johri, A.K., 2013. Role of pilus 
proteins in adherence and invasion of Streptococcus agalactiae to the lung and cervical epithelial cells. J. Biol. Chem. 288, 4023-4034.

Shewell, L.K., Harvey, R.M., Higgins, M.A., Day, C.J., Hartley-Tassell, L.E., Chen, A.Y., Gillen, C.M., James, D.B.A., Alonzo, F., Torres, V.J., 2014. The cholesterol-dependent cytolysins pneumolysin and streptolysin $\mathrm{O}$ require binding to red blood cell glycans for hemolytic activity. Proc. Natl. Acad. Sci. 111, E5312E5320.

Shi, W.-W., Jiang, Y.-L., Zhu, F., Yang, Y.-H., Shao, Q.-Y., Yang, H.-B., Ren, Y.-M., Wu, H., Chen, Y., Zhou, C.-Z., 2014. Structure of a novel O-linked N-acetyl-D-glucosamine (O-GlcNAc) transferase, GtfA, reveals insights into the glycosylation of pneumococcal serine-rich repeat adhesins. J. Biol. Chem. 289, 2089820907.

Siboo, I.R., Chaffin, D.O., Rubens, C.E., Sullam, P.M., 2008. Characterization of the accessory Sec system of Staphylococcus aureus. J. Bacteriol. 190, 6188-6196.

Spellerberg, B., Rozdzinski, E., Martin, S., Weber-Heynemann, J., Schnitzler, N., Lütticken, R., Podbielski, A., 1999. Lmb, a protein with similarities to the LraI adhesin family, mediates attachment of Streptococcus agalactiae to human laminin. Infect. Immun. 67, 871-878.

Starr, C.R., Engleberg, N.C., 2006. Role of hyaluronidase in subcutaneous spread and growth of group A streptococcus. Infect. Immun. 74, 40-48.

Stringaris, A.K., Geisenhainer, J., Bergmann, F., Balshüsemann, C., Lee, U., Zysk, G., Mitchell, T.J., Keller, B.U., Kuhnt, U., Gerber, J., 2002. Neurotoxicity of pneumolysin, a major pneumococcal virulence factor, involves calcium influx and depends on activation of p38 mitogen-activated protein kinase. Neurobiol. Dis. 11, 355-368.

Svensson, M.D., Sjöbring, U., Luo, F., Bessen, D.E., 2002. Roles of the plasminogen activator streptokinase and the plasminogen-associated $\mathrm{M}$ protein in an experimental model for streptococcal impetigo. Microbiology 148, 3933-3945.

Tang, J., Wang, C., Feng, Y., Yang, W., Song, H., Chen, Z., Yu, H., Pan, X., Zhou, X., Wang, H., 2006. Streptococcal toxic shock syndrome caused by Streptococcus suis serotype 2. PLoS Med. 3, e151.

Telford, J.L., Barocchi, M.A., Margarit, I., Rappuoli, R., Grandi, G., 2006. Pili in gram-positive pathogens. Nat. Rev. Microbiol. 4, 509.

Terao, Y., Kawabata, S., Kunitomo, E., Murakami, J., Nakagawa, I., Hamada, S., 2001. Fba, a novel fibronectin-binding protein from Streptococcus pyogenes, promotes bacterial entry into epithelial cells, and the fba gene is positively transcribed under the Mga regulator. Mol. Microbiol. 42, 75-86.

Tettelin, H., Nelson, K.E., Paulsen, I.T., Eisen, J.A., Read, T.D., Peterson, S., Heidelberg, J., DeBoy, R.T., Haft, D.H., Dodson, R.J., 2001. Complete genome sequence of a virulent isolate of Streptococcus pneumoniae. Science (80-. ). 293, 498-506.

Thayer, S.G., Waltman, W.D., Wages, D.P., 2008. Streptococcus and Enterococcus. Dis. Poult. 900-908. doi:10.1016/B978-0-7020-4089-4.00031-7

Timmer, A.M., Timmer, J.C., Pence, M.A., Hsu, L.-C., Ghochani, M., Frey, T.G., Karin, M., Salvesen, G.S., Nizet, V., 2009. Streptolysin O promotes group A Streptococcus immune evasion by accelerated macrophage apoptosis. J. Biol. Chem. 284, 862-871.

Ton-That, H., Schneewind, O., 2004. Assembly of pili in Gram-positive bacteria. Trends Microbiol. 12, 228234.

Ton-That, H., Schneewind, O., 2003. Assembly of pili on the surface of Corynebacterium diphtheriae. Mol. Microbiol. 50, 1429-1438.

Toppel, A.W., Rasmussen, M., Rohde, M., Medina, E., Chhatwal, G.S., 2003. Contribution of protein G-related $\alpha 2$-macroglobulin-binding protein to bacterial virulence in a mouse skin model of group A streptococcal infection. J. Infect. Dis. 187, 1694-1703.

Tripp, T.J., McCormick, J.K., Webb, J.M., Schlievert, P.M., 2003. The zinc-dependent major histocompatibility complex class II binding site of streptococcal pyrogenic exotoxin $\mathrm{C}$ is critical for maximal superantigen function and toxic activity. Infect. Immun. 71, 1548-1550.

Tweten, R.K., 2005. Cholesterol-dependent cytolysins, a family of versatile pore-forming toxins. Infect. Immun. 73, 6199-6209.

Usmani, S.M., von Einem, J., Frick, M., Miklavc, P., Mayenburg, M., Husmann, M., Dietl, P., Wittekindt, O.H., 2012. Molecular basis of early epithelial response to streptococcal exotoxin: role of STIM1 and Orai1 proteins. Cell. Microbiol. 14, 299-315.

van der Poll, T., Opal, S.M., 2009. Pathogenesis, treatment, and prevention of pneumococcal pneumonia. Lancet 374, 1543-1556.

Vengadesan, K., Ma, X., Dwivedi, P., Ton-That, H., Narayana, S.V.L., 2011. A model for group B Streptococcus pilus type 1: the structure of a $35-\mathrm{kDa}$ C-terminal fragment of the major pilin GBS80. J.

International Journal of Research Studies in Microbiology and Biotechnology (IJRSMB) $\quad$ Page | 36 
Mol. Biol. 407, 731-743.

von Pawel-Rammingen, U., Björck, L., 2003. IdeS and SpeB: immunoglobulin-degrading cysteine proteinases of Streptococcus pyogenes. Curr. Opin. Microbiol. 6, 50-55.

Waksman, G., Fronzes, R., 2010. Molecular architecture of bacterial type IV secretion systems. Trends Biochem. Sci. 35, 691-698.

Waldvogel, F.A., 2004. Infectious diseases in the 21st century: old challenges and new opportunities. Int. J. Infect. Dis. 8, 5-12.

Weiser, J.N., Bae, D., Fasching, C., Scamurra, R.W., Ratner, A.J., Janoff, E.N., 2003. Antibody-enhanced pneumococcal adherence requires IgA1 protease. Proc. Natl. Acad. Sci. 100, 4215-4220.

Wessels, M.R., Moses, A.E., Goldberg, J.B., DiCesare, T.J., 1991. Hyaluronic acid capsule is a virulence factor for mucoid group A streptococci. Proc. Natl. Acad. Sci. 88, 8317-8321.

Wu, Z., Li, M., Wang, C., Li, J., Lu, N., Zhang, R., Jiang, Y., Yang, R., Liu, C., Liao, H., 2011. Probing genomic diversity and evolution of Streptococcus suis serotype 2 by NimbleGen tiling arrays. BMC Genomics 12, 219.

Ye, C., Zhu, X., Jing, H., Du, H., Segura, M., Zheng, H., Kan, B., Wang, L., Bai, X., Zhou, Y., 2006. Streptococcus suis sequence type 7 outbreak, Sichuan, China. Emerg. Infect. Dis. 12, 1203.

Yen, Y.T., Cameron, T.A., Bensing, B.A., Seepersaud, R., Zambryski, P.C., Sullam, P.M., 2013. Differential localization of the streptococcal accessory sec components and implications for substrate export. J. Bacteriol. 195, 682-695.

Zhang, W., Rong, C., Chen, C., Gao, G.F., 2012. Type-IVC Secretion System : A Novel Subclass of Type IV Secretion System ( T4SS ) Common Existing in Gram- Positive Genus Streptococcus 7. doi:10.1371/journal.pone.0046390

Zhao, Y., Liu, G., Li, S., Wang, M., Song, J., Wang, J., Tang, J., Li, M., Hu, F., 2011. Role of a type IV-like secretion system of Streptococcus suis 2 in the development of streptococcal toxic shock syndrome. J. Infect. Dis. 204, 274-281.

Zhou, M., Zhu, F., Dong, S., Pritchard, D.G., Wu, H., 2010. A novel glucosyltransferase is required for glycosylation of a serine-rich adhesin and biofilm formation by Streptococcus parasanguinis. J. Biol. Chem. 285, 12140-12148.

http://www.paidb.re.kr/browse_pais.php?m=p\#Streptococcus pneumoniae

https://en.wikipedia.org/wiki/Streptococcus_pyogenes

https://microbeonline.com/virulence-factors-streptococcus-pyogenes-roles/

Citation: U. Seid, A. Demeke, "Review on Major Virulence Factors of Pathogenic Streptococcus Species ", International Journal of Research studies in Microbiology and Biotechnology, vol. 4, no. 2, p. 11-37, 2018. http://dx.doi.org/10.20431/2454-9428.0402003

Copyright: (C) 2018 U. Seid, A. Demeke. This is an open-access article distributed under the terms of the Creative Commons Attribution License, which permits unrestricted use, distribution, and reproduction in any medium, provided the original author and source are credited. 